\title{
Applying the Rome Statute of the International Criminal Court: A Case Study of Henry Kissinger
}

\author{
Steven Feldstein ${ }^{\dagger}$
}

Introduction

\section{TABLE OF CONTENTS}

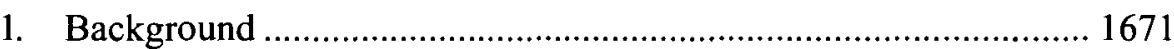

A. Henry Kissinger ................................................................ 1672

B. The Development of International Humanitarian Law .............. 1675

1. Sources of International Law ........................................... 1676

2. Historical Development of International Humanitarian

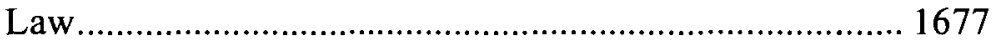

3. Post-World War Il Efforts to Codify 1nternational

Humanitarian Principles.................................................. 1680

a. The 1948 Genocide Convention.......................................1680

b. The Geneva Conventions ................................................. 1682

c. United Nations Suite of Human Rights Conventions......... 1684

C. The Development of International War Crimes Tribunals ....... 1685

1. Nuremberg Tribunal .................................................... 1685

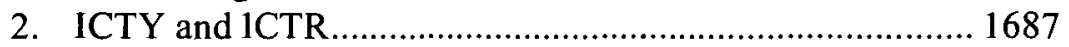

3. The International Criminal Court ..................................... 1688

4. Universal Jurisdiction........................................................ 1694

5. Alien Tort Claims Act .................................................... 1695

11. Individual Accountability Principles............................................. 1696

A. 1ndividual Criminal Responsibility......................................... 1697

1. The Rome Statute's Ascription of 1ndividual Criminal Responsibility ............................................................ 1697

Copyright $(C 2004$ California Law Review, Inc. California Law Review, Inc. (CLR) is a California nonprofit corporation. CLR and the authors are solely responsible for the content of their publications.

$\dagger \quad$ Steve Feldstein graduated from the School of Law, University of California, Berkeley (Boalt Hall) in May 2004. Currently he resides in Washington, D.C. and is a Presidential Management Fellow at the U.S. Agency for International Development in the Millennium Challenge Account Secretariat, where he coordinates programming and policy between the newly-ereated Millennium Challenge Corporation and USAID. His work focuses on poverty reduction and economic growth, anti-corruption activities, human capital development, and democraey and governanee under the overall umbrella of U.S. foreign assistance. 
2. Contemporary Application of Individual Criminal Responsibility: Prosecutor v. Kordic.................................. I698

B. Command Responsibility Doctrine ........................................ 1699

I. The Yamashita Standard .................................................. I699

2. Contemporary Application of Command Responsibility: Prosecutor v. Kordic......................................................... 170I

III. An Assessment of Whether Henry Kissinger Should Face a Hearing for Violations of International Humanitarian Law . 1702

A. The List of Allegations Against Kissinger. 1703

1. Allegation One: Responsibility and Culpability for "Secret" Bombing Campaigns in Neutral Laos and Cambodia, Beginning in 1969.

2. Allegation Two: Direct Approval and Assistance to Pakistan in Implementing Mass Civilian Killings in Bangladesh in 1971

3. Allegation Three: Colluding and Assisting with the 1970 Assassination of General Rene Schneider of Chile, a Country with which the United States Was Not at War.

4. Allegation Four: Enabling and Approving Mass Civilian Killings in East Timor by the Indonesian Government in 1975 .

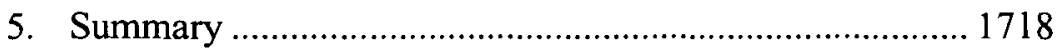

B. Available Defenses for Kissinger ....................................... I719

IV. Broader Policy Implications Behind the International Criminal Court.

A. Reduction of Culpability Under the Legal Analysis

B. Policy Implications of the Rome Statute 


\title{
Applying the Rome Statute of the International Criminal Court: A Case Study of Henry Kissinger
}

\author{
Steven Feldstein
}

\section{INTRODUCTION}

On November 27, 2002, Henry Kissinger reentered public life with a flourish. President George W. Bush named Kissinger to head an independent investigation of intelligence failures leading up to the September 11, 2001, terrorist attacks on the World Trade Center and the Pentagon. ${ }^{1}$ In naming Kissinger to the post, Bush stated, "Dr. Kissinger will bring broad experience, clear thinking and careful judgment to this important task." ${ }^{2} \mathrm{He}$ finished by thanking Kissinger for "returning to the service of [his] nation." ${ }^{3}$ With Kissinger's incipient reentry into public service, many old issues of foreign policy and accountability resurfaced, from bombings in Cambodia to mass civilian killings in East Timor. It was fitting that as the United States stood on the precipice of war in Iraq, one of the main architects and sponsors of U.S. military involvement in Indochina and a heavy handed practitioner of realist power politics, would be back on center stage. As it turned out, Kissinger's swan song would last a scant twentythree days, as he resigned the position "to remove any questions about even the appearance of a conflict of interest regarding his ties to several organizations and public figures." Ironically, the purported conflicts of interest were due to his business-related conflicts of interest and not because of any associated political controversies. ${ }^{5}$

This Comment focuses on Henry Kissinger as a potential defendant in the International Criminal Court because of his iconic status, as a symbol of unfettered institutional authority and power in a time of great political upheaval. By analyzing Kissinger's actions from a contemporary

1. Kissinger to Head 9-1/ Commission, CBSNews.com (Nov. 27, 2002), at http://www.cbsnews .com/stories/2002/12/12/politics/main532794.shtml.

2. $\quad$ ld.

3. Id.

4. Kissinger Resigns as Head of 9/11 Commission, CNN.com (Dec. 13, 2002), at http://www.cnn.com/2002/ALLPOLITICS/12/13/kissinger.resigns/.

5. In particular, Kissinger noted that conflicts involving his political-business consulting firm, Kissinger Associates, precluded his continuing involvement with the Commission. Id. 
perspective, this Comment takes advantage of the distance in time from the underlying events. This Comment analyzes the Rome Statute, ${ }^{6}$ the governing statute of the International Criminal Court (ICC), and presents a casestudy of Henry Kissinger-retroactively examining his actions as National Security Advisor and Secretary of State in the context of the Rome Statute-in order to further our understanding of how the Rome Statute might apply to potential defendants. This Comment is distinct from other attempts to ascribe liability to Kissinger because it applies a strict legal standard in its examination of Kissinger's actions.

Specifically, this paper poses two questions. First, under the Rome Statute, would Kissinger be liable for violations of international humanitarian law committed in his capacity as National Security Advisor and Secretary of State under the administrations of President Nixon and President Ford? The four events in question are: (1) responsibility for "secret" bombing campaigns in neutral Laos and Cambodia, beginning in 1969 ; (2) direct approval and assistance to Pakistan in implementing mass civilian killings in Bangladesh in I971; (3) colluding and assisting with the 1970 assassination of General Rene Schneider of Chile, a country with which the United States was not at war; and (4) enabling and approving mass civilian killings in East Timor by the Indonesian government in 1975. A note of caution, this Comment does not intend to stand in as a bill of indictment against Henry Kissinger. It would be improper to apply current international criminal law standards ex-post to actions undertaken thirty years prior, when lawmakers had yet to uniformly apply these same principles. ${ }^{7}$ This Comment argues that despite the litany of critics who charge Kissinger with a host of war crimes violations, when we apply a legal framework under the Rome Statute, we find that Kissinger would face liability for prima facie violations of international humanitarian law in only the first of the four allegations presented in this Comment. ${ }^{8}$

Second, what does this analysis indicate about the strengths and weaknesses of the ICC as an institution? This Comment contends that Kissinger's diminished liability under the Rome Statute does not necessarily implicate the ICC as a weak or illegitimate institution; rather, it reflects the deliberate design of the ICC as a body meant to prosecute only the highest-ranking perpetrators of the most heinous crimes in international law.

6. Rome Statute of the International Criminal Court, U.N. Doc. A/CONF.183/9 (1998) [hereinafter Rome Statute] available at http://www.un.org/law/icc/statute/romefra.htm.

7. Moreover, it is important to note that the $1 \mathrm{CC}$ only has jurisdiction over events that occurred after July 1, 2002. Id. at art. 11 .

8. This Comment settled on the four enumerated allegations through compilation and review of a variety of literature that discusses Kissinger's actions. This includes bodies of work by Christopher Hitchens, Seymour Hersh, William Shawcross, and Walter Isaacson. For a complete list of sources reviewed and used to compile the evidentiary record, see infra note 213. 
This topic is particularly relevant to the current legal and political climate for several reasons. First, with the war in Iraq and the scope of the war on terrorism ${ }^{9}$ comes renewed interest in the level of accountability and liability that U.S. officials should face for alleged violations of international humanitarian law undertaken within a military or civilian capacity. Second, with the ratification of the International Criminal Court in 2002 and its ascendance as a major instrument of international criminal law, it is critical to examine the nature and scope of how the ICC would apply to the actions of a leading government official like Kissinger and how that examination illustrates the strengths and weaknesses of the ICC. ${ }^{10}$

In the past decade, there has been a renewed effort to hold high-level political and military figures accountable for international criminal actions, including war crimes. With the establishment of the Nuremburg Tribunal in 1945 and the subsequent indictment of twenty-four leading Nazi officials, it seemed that the world was entering a new age where genocide, war crimes, and related human rights atrocities would not be tolerated under international Iaw. "Unfortunately, this prognostication proved to be tragically idealistic. In the ensuing years, the world experienced a rash of killings and atrocities that include the world's third great genocide (Rwanda), ${ }^{12}$ auto-genocide (Cambodia), possible genocide (East Timor), ethnic cleansing (Former Yugoslavia), as well as boiler-plate human rights violations initiated by a panoply of dictators including Augusto Pinochet, Pol Pot, Mao Tse-teng, Joseph Stalin, Nicolae Ceausescu, Slobodan Milosevic, Suharto, Kim II Sung, Joseph Mobutu, and Idi Amin to name a few. ${ }^{13}$

9. The war on terrorism, which President George W. Bush announced to the world in his September 20, 2001 address to Congress, generally refers to the actions undertaken by the United States in response to the September 11 attacks. This includes but is not limited to the twin U.S. interventions in Afghanistan and Iraq. Address to a Joint Session of Congress and the American People, Whitehouse.gov (Sept. 20, 2001) at http://www.whitehouse.gov/news/releases/2001/09/ 20010920-8-html.

10. It is important to distinguish between the terms "ratification" and "signing." A state's ratification of a particular treaty entails its consent to be bound in international law by that treaty. The mere signing of a treaty is not equally binding. The Rome Statute held that sixty states must ratify the treaty hefore it would enter into force as a hinding instrument in international law- "Anyone who commits any of the crimes under the Statute after this date is liable for prosecution by the Court." Chronology of the International Criminal Court, 1CC-CPI.int, at http://www.icc-cpi.int/ataglance/ whatistheicc/chronology.html (last visited Aug. 19, 2004).

11. See Yves Beigbeder, Judging Criminal Leaders 44 (2002) (positing that despite the best intentions of the Nuremberg Tribunal, it has failed to prevent the recurrence of instances of genocide).

12. See Mark Huband, Rwanda-The Genocide, CrimesOfWar.org, http://www.crimesofwar.org/ thebook/rwanda-the-genocide.html (last visited Aug. 19, 2004) (discussing the use of the term "genocide" with regard to the Rwandan civil war of 1994).

13. See id. at 13-48 (offering a comprehensive survey of the leading massacres and genocides of the twentieth century); see generally Crimes of WAR: What the Public Should Know (Roy Gutman \& David Rieff eds., 1999) [hereinafter CRIMEs OF WAR] (presenting a broad perspective of twentieth century war crimes). 
Despite the bleak human rights landscape of the twentieth century, two major events shifted momentum back toward a justice and accountability model based on international law. First, the close of the Cold War and the end of the bipolar superpower framework permitted the ascension of the United Nations as a major institutional force in world politics. ${ }^{14}$ Second, the contemporaneous explosion in violence and ethnic slaughter eventuating in genocide in Rwanda and the Former Yugoslavia precipitated renewed cries for a forum in which to redress war crimes and other human rights abuses. ${ }^{15}$

Thus, in 1993, the United Nations authorized the creation of the International Criminal Tribunal for the Former Yugoslavia (ICTY). ${ }^{16}$ On November 8, 1994, the United Nations Security Council passed Resolution 955, which established an international justice tribunal for Rwanda (ICTR) in response to a genocide that had claimed upwards of 800,000 civilians. $^{17}$

The two tribunals (whose efforts are still ongoing) have left an immediate legacy upon which the international community has seized. First, they have rendered judgments that have fundamentally altered the nature of and manner in which war crimes are prosecuted. For instance, in February 2001 the 1CTY established, for the first time, rape as a crime against humanity in the Kunarac, Kovac, and Vukovic Case. ${ }^{18}$ As for the ICTR, in December 2001, the tribunal sentenced former Prime Minister Jean Kambanda, the highest-ranking official to be convicted of a war crime since Nuremberg, to life imprisonment. ${ }^{19}$

Second, the creation of the ICTY and ICTR has resulted in increased efforts to hold human rights violators accountable and establish permanent mechanisms under which to prosecute them. To that end, the United Nations authorized the creation of the ICC in 1998, which became operational on July $1,2002 .{ }^{20}$ The ICC's formation is significant because unlike the ICTY or the ICTR, which were established on an ad hoc basis and whose jurisdiction is strictly limited by time and geography, the ICC is a

14. See generally United Nations, Basic Facts About the United Nations, at http://www.un.org/ aboutun/basicfacts/unorg.htm (last visited May 29, 2004) (discussing the ascendance of the UN into the forefront of world politics).

15. See BeIGBEDER, supra note 11, at 50, 104 (noting the lack of an appropriate forum in which to address these violations).

16. S.C. Res. 827, U.N. SCOR, 48th Sess., 3217th mtg., U.N. Doc. S/RES/827 (1993) [hereinafter Resolution 827] (establishing the ICTY).

17. S.C. Res. 955, U.N. SCOR, 49th Sess., 3453d mtg., U.N. Doc. S/RES/955 (1994) [hereinafter Resolution 955] (establishing the ICTR).

18. Press Release, United Nations, Judgment of Trial Chamber II in the Kunarac, Kovac and Vukovic Case (Feb. 22, 2001), http://www.un.org/icty/pressreal/p566-e.htm.

19. Foundation Hirondelle, Ex-Rwandan Premier Moved to Mali to Serve Genocide Sentence, at http://www.hirondelle.org/hirondelle.nsf/caefd9edd48f5826c12564cf004f793d/0a30a56f67fb8bd9c125 66730043be94? OpenDocument (last visited May 29, 2004).

20. United Nations, Rome Statute of the International Criminal Court Overview, at http://www.un.org/law/icc/general/overview.htm (last visited Mar. 21, 2004). 
permanent institution that has jurisdiction over four enumerated crimes (genocide, crimes against humanity, war crimes, and the crime of aggression) committed within a signatory country or by the citizen of a signatory country. ${ }^{21}$ Thus, if a French citizen planted a bomb in Algeria killing five Algerian nationals the case could be directly referred to the ICC without the need to establish a special commission or tribunal because France is a party to the ICC. ${ }^{22}$ Further, individual countries are beginning to take matters into their own hands and to increase the scope and pace of prosecution of human rights violators. To that end, the Pinochet case stands as a milestone. In 1998, a Spanish court issued an international arrest warrant against Augusto Pinochet for acts of torture, hostage taking, and other activities undertaken during his time in power. ${ }^{23}$ Later that year British authorities arrested him pursuant to that warrant. ${ }^{24}$ Pinochet challenged the arrest, but eventually the House of Lords ruled that "despite his status as a former head of state, Pinochet was not entitled to immunity from arrest and extradition on the specific charges of torture and conspiracy to commit torture." ${ }^{25}$ Not only is this case significant because two separate countries affirmed their willingness to prosecute former heads of state despite traditions of sovereign immunity, but it also indicates an increasing trend towards the principle of universal jurisdiction-the idea that every state has an interest in bringing to justice the perpetrators of certain crimes of universal concern, no matter where the crime was committed, and notwithstanding the nationality of the perpetrator or the victims. ${ }^{26}$ Thus we reach the subject matter of this Comment: an examination of whether Henry Kissinger would face a hearing for violations of international humanitarian law under the Rome Statute and what that examination teaches about the strengths and weaknesses of the ICC.

21. William A. Schabas, An Introduction to the International Criminal Court I76 (2001)

22. It is important to emphasize that the ICC subscribes to the principlc of "complementarity," which stands for the proposition that the Court "would be a last resort which comes into play only when domestic authorities are unable or unwilling to prosecute." Michael P. Scharf, The Case for Supporting the International Criminal Court, in International Debate Series: Should the United States Ratify the Treaty Establishing the International Criminal Court? 5, 7 (Whitney R. Hatris Institute for Global Legal Studies, Washington University School of Law, 2002), available at http://law.wustl.cdu/igls/InternationalDebate/International\%20DebateSeriesiCCPapersENTIRE.pdf.

Morcover, under the Court's statute, "the Prosecutor has to notify [s] tates with a prosecutive interest in a case of his/her intention to commence an investigation." Id. It is not the ICC's intention to substitute for national courts of justice.

23. Gilbert Sison, A King No More: The Impact of the Pinochet Decision on the Doctrine of Head of State Immunity, 78 WASH. U. L.Q. 1583, 1583 (2000).

24. Id.

25. Sarah C. Rispin, Implications of Democratic Republic of the Congo v. Belgium on the Pinochet Precedent: A Setback for International Human Rights Litigation?, 3 CHI. J. INT'L L. 527, 528 (2002).

26. Reed Brody, Justice and The Generals: Universal Jurisdiction, at http://www.pbs.org/ wnet/justice/world_issues_uni.html (last visited Mar. 18, 2004). 
This Comment incorporates the works of Christopher Hitchens (one of Kissinger's most prominent critics) and others (including Kissinger's own biography) in order to develop an evidentiary basis upon which to determine whether Kissinger would face a hearing for international humanitarian law violations. Ultimately, this Comment contends that, under a strict legal standard based on the Rome Statute, Kissinger would only face liability for one of the four allegations analyzed in this Comment, namely, his responsibility and culpability for "secret" bombing campaigns in neutral Laos and Cambodia beginning in 1969. This analysis may fly in the face of analyses by Hitchens and others, but the crucial difference is that their analyses fail to examine Kissinger from a legal perspective, based on contemporary international norms. Rather, their logic is rooted in moral outrage, which often is separate and distinct from what the law itself dictates.

This examination of Kissinger's actions leads this Comment to make the following assertion about the strengths and weaknesses of the ICC: its role, purpose, and design reflect the desire of the international community to provide a forum in which to try the highest-ranking perpetrators of the most heinous crimes. The ICC is not meant to serve as an all-purpose justice tribunal and, therefore, were the Rome Statute applied to Kissinger, he could be recused from three of the four allegations.

Part I of this Comment presents Henry Kissinger's background, traces the development of international humanitarian law and international human rights protections, and examines the historical progression of international justice tribunals, culminating with a discussion of the recently established ICC. It also examines the doctrine of universal jurisdiction and the Alien Tort Claims Act (ATCA). This Part seeks to provide a historical-legal framework which will assist with the subsequent analysis of Kissinger's actions. Part II presents and analyzes individual accountability principles to which Kissinger may be subject, including individual criminal responsibility and the command responsibility doctrine. These represent the particular theoretical and legal principles which this Comment will utilize in analyzing Kissinger. Part III then applies this international legal framework to Kissinger's background, actions, and position with regard to the four specific allegations in assessing whether sufficient justification exists for Kissinger to face a hearing at the ICC. Part IV discusses broader policy implications for the ICC that follow from this analysis of Kissinger. Overall, this Comment intends to provide the reader with a greater understanding as to how the ICC may serve as a venue for the adjudication of a high official like Kissinger, and insight into the policy implications of the ICC. 


\section{BACKGROUND}

Kissinger is a widely-acclaimed statesman and has served in some of the highest governmental positions in this country, including stints as National Security Advisor and Secretary of State ${ }^{27} \mathrm{He}$ was even the recipient of the 1973 Nobel Peace Prize for his role in peace negotiations to end U.S. involvement in the Vietnam War. ${ }^{28}$ There is, however, another side to Kissinger. Critics have accused him of atrocities, including authorizing indiscriminate and illegal bombing campaigns in Laos and Vietnam, facilitating the assassination of Chilean General Rene Schneider, and abetting mass slaughter in East Timor. ${ }^{29}$

This Comment focuses on Kissinger's actions between 1969 and 1977 when he served as National Security Advisor (1969-75) and Secretary of State (1973-77) to the Nixon and Ford administrations respectively. ${ }^{30}$ Part A presents personal background information about Kissinger before these time periods to better understand the motivation behind his choices and decisions. Part B outlines the development of international humanitarian law to provide a theoretical framework in which to place Part C. Part C describes the development of the international war crimes tribunals, such as the Nuremberg Tribunal, the ICTY and ICTR, and the ICC. This Part also provides the legal background on the concept of universal jurisdiction, as well as the ATCA, which allows non-citizens to sue in the U.S. for human rights torts, such as war crimes and torture.

27. Nobel e-Museum, Henry Kissinger-Biography, http://www.nobel.se/peace/laureates/1973/ kissinger-bio.html (last visited Mar. 19, 2004) [hereinafter Kissinger Biography].

28. Id.

29. Recently, author and journalist Christopher Hitchens wrote a widely distributed book, THE TRIAL OF HENRY KISSINGER, which catalogues in comprehensive detail the specific crimes for which Kissinger should be held accountable. Christopher Hitchens, The Trial of Henry Kissinger (2002). Indeed, Hitchens has seized the mantle quite forcefully. He opens his book: "It will become clear, and may as well be stated at the outset, that this book is written by a political opponent of Henry Kissinger. Nonetheless, 1 have found myself continually amazed at how much hostile and discreditable material $\mathrm{l}$ have felt compelled to omit." Id. at ix. Further, he contends:

A failure to proceed [against Kissinger] will constitute a double or triple offense to justice.

First, it will violate the essential and now uncontested principle that not even the most powerful are above the law. Second, it will suggest that prosecutions for war crimes and crimes against humanity are reserved for losers, or for minor despots in relatively negligible countries. This in turn will lead to the paltry politicization of what could have becn a noble process, and to the justifiable suspicion of double standards.

$I d$. at $\mathrm{xi}$. Hitchens raises troubling questions. For example, does the scope and nature of international accountability prosecutions refleet a bifurcation of justice between the haves of the world and the havenots (i.e. the ICTY will target a second-rate leader like Serbian President Slobodon Milosevic, while overlooking the actions of U.S. officials and leaders)? Does our failure to bring Kissinger before a national court or an international tribunal reflect a "shrugging off" of a universal responsibility to hold perpetrators of war crimes and crimes against humanity accountable for their actions? However, many of Hitchens's accusations more closely resemble generalized moral outrage than legally grounded indictments. As this Comment argues, these accusations tend to fall apart under a closer legal analysis.

30. Kissinger Biography, supra note 27. 


\section{A. Henry Kissinger}

Born in Fuerth, Germany, on May 27, 1923, at the age of fifteen, barely three months before the mobs of Kristallnacht would destroy synagogues and most other Jewish institutions across Germany as a precursor to the Holocaust, Kissinger and his family fled Germany for England and later the United States. ${ }^{31}$ Thus, perhaps a key insight into Kissinger's stubborn realpolitik ${ }^{32}$ political perspective is that one of his defining childhood moments was being cast as a refugee and forced to flee his homeland for a foreign territory. Not only did Kissinger later adopt a realist, realpolitik approach that sought to preserve order through balances of power instead of an idealistic, moralist approach, but as Walter Isaacson notes in his biography on Kissinger, "Given a choice of order or justice, [Kissinger] often said, paraphrasing Goethe, he would choose order. He had seen too clearly the consequences of disorder." 33 This philosophical perspective would manifest itself repeatedly in the foreign policy choices Kissinger would later make in the public realm.

Growing up in the United States, Kissinger appeared destined to follow in the footsteps of his father and become an accountant. ${ }^{34}$ However, those plans were derailed when he received his army draft notice in February $1943 .{ }^{35}$ As a private in the army, he quickly gained the notice of his superiors and eventually was transferred to the Counter-Intelligence Corps to serve as an agent. ${ }^{36}$ In July 1947 , Kissinger's tour of duty was over and he returned to the United States. ${ }^{37} \mathrm{He}$ decided to apply for admission to Harvard and, in the fall of 1947 , he became part of the class of 1950 , his education financed in part by the GI Bill. ${ }^{38}$ He graduated summa cum laude from Harvard in 1950 with a degree in government, and subsequently received his M.A. and Ph.D. degrees from Harvard in 1952 and 1954 respectively. ${ }^{39}$

After receiving his Ph.D., Kissinger cast around in a number of directions. He lectured at Harvard and won tenure serving in a variety of

31. WALTER ISAACSON, KISSINGER 20-21, 28, 356 (1992). Isaacson notes that Kissinger has rarely spoken of the Holocaust other than to protest occasionally that it did not leave a permanent scar on his subconscious. Only once did Kissinger divulge any signs of anger over what happened: "During an early visit to Germany as national security advisor, Bonn announced that Kissinger might visit with some of his relatives. 'What the hell are they putting out?' he grumbled to aides. 'My relatives are soap." Id. at 29.

32. Kissinger's realpolitik perspective will be discussed in detail in the following section. See infra Part I.B.

33. Id. at 31 .

34. Id. at $43-48$.

35. Id.

36. Id.

37. Id. at 57-58.

38. Id. at 59 .

39. Kissinger Biography, supra note 27. 
positions, including Associate Director of the Center for International Affairs and Director of the Harvard Defense Studies Program ${ }^{40}$, he accepted a post at the Council of Foreign Relations; and he wrote a book in 1960, The Necessity of Choice, which many read as a "job application in case the new president [Kennedy] decided to seek some fresh thinking from Cambridge. ${ }^{241}$ On the basis of the book and other assorted critical writings of the Eisenhower administration, Kissinger rose in prominence in the Democratic Party ranks and was a prime candidate for a position in the Kennedy administration, although this never materialized. ${ }^{42}$ Additionally, Kissinger was a close advisor to New York Governor Nelson Rockefeller, a "liberal" Republican, and Kissinger integrally assisted with Rockefeller's 1968 presidential campaign against Richard Nixon for the Republican nomination. ${ }^{43}$ Rockefeller lost the Republican primary, and Kissinger eventually shifted over to Nixon's camp, helping Nixon capture the presidency from Hubert Humphrey ${ }^{44}$ It was at this point that the first in a long line of controversies arose regarding Kissinger's conduct. While the HumphreyNixon race was ongoing, the Johnson administration was also involved in peace negotiations to end the Vietnam War. Kissinger allegedly held a series of secret meetings with the South Vietnamese side, informing them that the Republicans could offer them a better deal than the Democrats and to hold off on negotiating until after the election. ${ }^{45}$ As a result, South Vietnam head of state Nguyen Van Thieu unexpectedly pulled out of the peace talks, sabotaging any efforts at rapprochement and potentially killing Humphrey's shot at the presidency. ${ }^{46}$ Following Nixon's victory, Nixon offered Kissinger the position of Assistant to the President for National Security Affairs, beginning Kissinger's eight-year run as the guiding force behind U.S. foreign policy. ${ }^{47}$

Kissinger's legacy is decidedly mixed. On the one hand, he was instrumental in organizing and arranging some of the seminal events of our

40. Id.

41. ISAACSON, supra note 31 , at 105 .

42. Id. at 109 .

43. Id. at $124-26$.

44. Id. at 129. It is interesting to note that while serving Rockefeller, Kissinger was extremely disdainful of Nixon. Isaacson writes: "[Kissinger] would rail against Nixon's 'shallowness', his 'dangerous misunderstanding' of foreign policy.... Kissinger helped keep the 'black book' of clippings on Nixon, which the campaign used to guide attacks. Among its chapter headliners were 'The Tricky Diek Syndrome' and 'The Loser Image."' $1 d$. at 127.

45. Seymour M. Hersh, The Price of Power: Kissinger in the Nixon White House 21-22 (1983).

46. Id. at 21. Hitchens writes about the election:

Indeed it was a very close-run election, turning in the end on a difference of a few hundred thousand votes, and many hardened observcrs believe that the final diffcrence was made when Johnson ordered a bombing halt on 31 October and the South Vietnamese made him look a fool by boycotting the peace talks the very ncxt day.

HitCHENS, supra note 29, at 14.

47. Id. 
time, including the signing of the Strategic Arms Limitation Talks (SALT) in May 1970 with the Soviets and arranging summits with China's Mao Zedong in February 1972 and the Soviet Union's Leonid Brezhnev in May $1972 .{ }^{48}$ In 1973, Kissinger even received the Nobel Peace Prize along with chief North Vietnamese negotiator Le Duc Tho for their roles in ending the Vietnam War with the signing of the Paris Peace Agreement. ${ }^{49}$ It is ironic that the 1973 agreement is almost identical to the terms of the 1968 version, which Kissinger originally helped sabotage. ${ }^{50}$ On the other hand, Kissinger left a legacy of amoral policy-making (i.e. deciding to ignore reports of Pakistani military civilian massacres in order not to jeopardize the China Summit), unprecedented consolidation of power, and realpolitik maneuverings. ${ }^{51}$

In the realm of political ideology, Kissinger is the contemporary standard-bearer for a line of reasoning known as "realpolitik." Realpolitik, which is also known as "realism" and derives from a nineteenth-century European tradition, denotes "the belief that individual nations could be understood in terms of their particular interests, and that foreign policy was the art and science of satisfying those interests through diplomacy, alliance, economic promise or pressure, threats, and when necessary, war." ${ }^{, 52} \mathrm{Or}$ as Kissinger himself describes it, realpolitik is "foreign policy based on calculations of power and the national interest." ${ }^{.53}$ Ultimately, realpolitik is based on two conceptions: a pessimistic view of human nature and that power is paramount in international relations. ${ }^{54}$

For instance, when deliberating over peace agreements to the Vietnam War, the first concern of Kissinger (and any other realist) would not be to negotiate a settlement solely for the purpose of achieving "peace." The concept of "peace" as a lofty and idealistic goal would not, per se, interest Kissinger. Instead, he would construct a cost/benefit analytical framework and ask, what would peace do for our position? What would we have to give up to achieve peace? From the administration's perspective, would it make sense to reach a peace settlement now, or would we be better off waiting (and fighting) for a few more years? The cost of lives, both to U.S. soldiers and Vietnamese civilians, would be just one factor to plug into the

48. IsAACSON, supra note 31 , at 316,399 .

49. Nobel e-Museum, The Nobel Peace Prize 1973, at http://www.nobel.se/peacc/laureates/1973 (last visited May 29, 2004).

50. HitcheNs, supra note 29 , at 15.

51. Id. at 47 .

52. David A. Westbrook, Law Through War, 48 BuFF. L. Rev. 299, 304 (2000).

53. HenRy Kissinger, Diplomacy 137 (1994).

54. IsaACson, supra note 31 , at 653 . This is opposed to the liberalist tradition, which assumes that the natural condition of international law is harmonious, and that conflict is best viewed as an aberration: "War was an irrational force to be contained by human reason." Note, Realism, Liberalism, and the War Powers Resolution, 102 HaRv. L. Rev. 637, 641 (1989). The United Nations is a primary example and outgrowth of liberalist thinking. Id. 
larger geopolitical equation. In fact, while this paper frames this example as a hypothetical, it is very close to the line of reasoning that Kissinger employed when negotiating the Paris Peace Agreement to end U.S. involvement in the Vietnam War. As one expert described Kissinger, "He tried to apply the formula of force and diplomacy, as he had applied it in Indochina and wanted to restore a new world order of peace on the basis of power and balance theories, which was practically not possible." 55

In many senses, the choices made by Kissinger, such as, whether to collude in the assassination of a Chilean official or tacitly approve the violent Indonesian "cleansing" of East Timor, were a function of his unwavering adherence to realist thought, even if it resulted in a complete separation of the ethical from the action. Characterizing Kissinger as a realist is not meant to provide justification for the alleged crimes that he committed, rather it is a means by which to better understand the choices he made in the given context. ${ }^{56}$

Before turning to the particulars of the four charges in Part III, this paper will first provide a theoretical background to the development of international humanitarian law and individual criminal accountability.

\section{B. The Development of International Humanitarian Law}

The idea of compelling a political or military leader like Kissinger to face a hearing for violations of international humanitarian law is not a new one. The concepts of war crimes, laws of war, and international humanitarian law can be traced back to antiquity. ${ }^{57}$ The actual term "international law" was first put forth by Jeremy Bentham in I780 in Introduction to the Principles of Morals and Legislation. ${ }^{58}$ Generally, international law is divided into public and private spheres. Our concern is with public international law, best defined as "the law that governs the relations between states amongst each other." 59 Within this broad stratum of public international law lie numerous sub-categories. Most relevant to this Comment is the principle of international humanitarian law. This section first explains the sources of international law. It then describes the historical development of international humanitarian law. Finally, this section examines three post-World War II efforts to codify international humanitarian law principles.

55. Annpurna Nautiyal, Henry Kissinger in World Politics 49 (1987).

56. For another perspective on how realpolitik shaped the development of Kissinger, see Elizabeth Kopelman, The Modern Machiavelli: Legitimacy, Conflict and Power in the International Legal Order, 43 UCLA L. Rev. 139 (1995) (reviewing Henry Kissinger, DiPlomacy (1994)).

57. Peter Malanczuk, Akehurst's Modern Introduction to International Law 1 (7th ed. 1997).

58. Id. The idea itself of international law or the "law of nations" can be traced back to the Roman concept of ius gentium and the writings of Cicero. Id.

59. Id. 


\section{Sources of International Law}

We know which treaties and laws to apply to Kissinger's situation by examining the sources of international law-or what gives international law its potential binding force. Article 38 of the Statute of the International Court of Justice, which is part of the United Nations Charter, provides a basic summary for international law:

1. The Court, whose function is to decide in accordance with international law such disputes as are submitted to it, shall apply:

a. international conventions, whether general or particular, establishing rules expressly recognized by the contesting states;

b. international custom, as evidence of a general practice accepted as law;

c. the general principles of law recognized by civilized nations;

d. subject to the provisions of Article 59, judicial decisions and the teachings of the most highly qualified publicists of the various nations, as subsidiary means for the determination of rules of law.

2. This provision shall not prejudice the power of the Court to decide a case ex aequo et bono, if the parties agree thereto. ${ }^{60}$

In the hierarchy of international law, conventions and treaties, like the Rome Statute, take precedence over international custom, which in turn has priority over general principles of law and judicial decisions. ${ }^{61}$

60. Statute of the Intemational Court of Justice, June 26, 1945, art. 38, 33 U.N.T.S. 993, available at http://www.icj-cij.org/icjwww/ibasicdocuments/ibasictext/ibasicstatute.htm\#CHAPTER_ 11.

61. However, Article 38 is best thought of only as a beginning; many posit that while treaties and custom remain the principal means by which international law is made, "[g]eneral principles of law have proved most useful in 'new' areas of international law." MALANCZUK, supra note 57, at 49. Sources of this body of law include international organizations, regional bodies, multinational enterprises, and non-governmental organizations. Id. at 48-50. Generally, the Vienna Convention on the Law of Treaties governs the use and procedure of treaties. 1t holds as its cardinal principle the idea of pacta sunt servanda-that every treaty in force is binding upon the parties to it and must be performed by them in good faith. Vienna Convention on the Law of Treaties, May 23, 1969, art. 26, 1155 U.N.T.S. 331 (entered into force Jan. 27, 1980) [hereinafter Vienna Convention]. International custom, on the other hand, is a less formalized set of rules that is not codified but is nonetheless binding upon states. See Iran-United States Claims Tribunal: Interlocutory Award in Case Concerning Sedco, Inc. and National Iranian Oil Company and Iran, 25 1.L.M. 629, 633 (1986) (discussing the use of custom in international law). This includes, for example, the concept of opinion juris - the sense of obligation that transforms mere usage or practice into law. Id. Beyond custom are softer instruments of law that serve as "gap fillers" between treaties and custom, or represent emerging fields of law (such as human rights law in the mid-twentieth century). MALANCZuK, supra note 57, at 54. Finally, holding even more force and applicability than treaties is the principle of jus cogens, or peremptory norms. Jus cogens is a universally accepted norm from which no derogation is permitted. See generally id. at 57 (discussing the inherent force of jus cogens norms). A universally accepted norm such as the idea that genocide should be absolutely and strictly prohibited is an example of a jus cogens norm. The only way to overrule this standard would be if another peremptory norm took its place-for example, if sovereignty 


\section{Historical Development of International Humanitarian Law}

Under international law, there are two aspects of war-why it is fought and how it is fought, or jus ad bellum and jus in bello. ${ }^{62}$ These two branches are separate from each other for the simple fact that it is possible to fight an unjust war while still adhering to the laws of combat. Jus ad bellum, or whether resort to force is justified, is the title given to the branch of law that determines the legitimate reasons a state may or may not engage in war. ${ }^{63}$ Jus ad bellum is intricately connected to just war theory, and it attempts to address whether there is a just cause for a conflict, and whether force is being used as a last resort. ${ }^{64} \mathrm{Jus}$ in bello, or whether a particular form of the use of force is justified, is the idea that war should not be unlimited and that "the ravages of war should be mitigated as far as possible...." This is more immediately relevant to the Kissinger case. Its concern is how a war is fought, regardless of whether it is just. ${ }^{66}$ International humanitarian law, such as the Geneva Convention and

became a more prioritized concept than the prevention of war crimes and thus if one's sovereignty were threatened, it would be acceptable to engage in crimes of war. Jus Cogens is defined and codified in Article 53 of the Vienna Convention which states:

For the purposes of the present Convention, a peremptory norm of general international law is a norm accepted and recognized by the international community of States as a whole as a norm from which no derogation is permitted and which can be modified only by a subsequent norm of general international law having the same character.

Vienna Convention, supra, at art. 53

62. MALANCZUK, supra note 57 , at $306,342$.

63. Id. at 306. The principal modern legal source for jus ad bellum can be found in Article 2 and Article 51 of the United Nations Charter. Article 2 states: "All members shall refrain in their international relations from the threat or use of force against the territorial integrity or political independence of any state, or in any other manner inconsistent with the Purposes of the United Nations." U.N. ChARTER art. 2, para. 4. Article 51 declares: "Nothing in the present Charter shall impair the inherent right of individual or collective self-defense if an armed attack occurs against a Member of the United Nations...." Id. at art. 51. Generally, the Charter maintains that force is justifiable in a limited number of instances: to "maintain international peace and security," including taking collective measures "for the prevention and removal of threats to the peace," and as a means to engage in individual or collective self-defense. Id. at art. 1.

64. MALANCZUK, supra note 57, at 306. In 1928, the International Treaty for the Renunciation of War as an Instrument of National Policy (the Kellogg-Briand Pact), attempted to outlaw aggrcssive war. General Treaty Providing for the Renunciation of War as an Instrument of National Policy, Aug. 27, 1928, 46 Stat. 2343, 94 L.N.T.S. 57. Thus, the answer to the question posed by jus ad bellum was answered: states deemed aggressive war illegitimate and a violation of international law. While clearcut in principle, administcring legal tests of jus ad bellum have been difficult; parties have fiercely debated ambiguities over whether aggressive law was specifically labeled a "crime" by the KelloggBriand Pact, most prominently at Nuremberg. These debates continue to the present; the ICC has yet to include the crime of aggression in its governing statute because of continuing debate. MALANCZUK, supra note 57 , at 342 .

65. Telford Taylor, Nuremberg and Vietnam 20 (1970).

66. The basic notion of just war theory is that if war cannot be prevented, at lcast it can be administered within certain limits, such as excluding civilians from the conflict, administering a rational prisoner exchange system, and proscribing certain types of weapons from the arena of warfare. MalanCZuK, supra note 57, at 342. 
Genocide Convention, stems directly from jus in bello ${ }^{67}$ International humanitarian law then is the set of rules governing the actors, both combatants and non-combatants, in times of military conflict. ${ }^{68}$

International humanitarian law has a long and storied background, and efforts to apply it can be traced back to the fifteenth century. ${ }^{69}$ It was not until the nineteenth century that formal international agreements embodying the principal concepts of the laws of war were drafted and enacted. ${ }^{70}$

67. Most lawyers, human rights groups, and most States, as well as the International Committee of the Red Cross (ICRC), favor using the term "international humanitarian law," while most militaries prefer the term "laws of war." ICRC, InTERnational Humanitarian LAw: ANSwERs To Your Questions, 4 (2002), available at http://www.icrc.org/Web/Eng/siteeng0.nsf/htmlall/p0703/\$File/ ICRC_002_0703.PDF!Open.

68. Id. ICRC defines international humanitarian law as "the rules which, in times of armed conflict, seek to protect people who are not or are no longer taking part in the hostilities, and to restrict the methods and means of warfare employed." Id.

69. Aryeh Neier, War Crimes: Brutality, Genocide, Terror, and the Struggle for JUSTICE 12 (1998). The first documented instance of an international justice tribunal for war crimes occurred in 1474 in Breisach, Germany, where twenty-seven judges of the Holy Roman Empire sat in judgment of Peter van Hagenback, who was charged with violating the "laws of God and man" by allowing his troops to rape, murder and pillage. He was convicted and duly executed. Id. Even before the Hagenback trial, customary protocol of war engagement was known and followed. As far back as the time of the ancient Greeks, strict (though unwritten) rules of war were followed. Over the ensuing centuries, the laws of war followed several streams of influence. A prominent line of thought, for example, stemmed from medieval notions of chivalry. Among its stipulations was the prohibition of the use of deceptions, such as wearing the enemy's uniform, or the "launching of a war without fair warning by formal declaration." TAYLOR, supra note 65 , at 20 . A second and more important concept was the belief that the "ravages" of war should be minimized as much as possible. To that end, civilian populations should be shielded from indiscriminate attacks; death and destruction not related to the "conduct of hostilities" should be avoided. This second stream was extremely influential towards the formation of formal rules of engagement. Id. The first formal codifieation of the laws of war was undertaken by Dutch scholar Hugo Grotius in 1625. NeIER, supra at 13. In his book, DE JURE BELLI AC PACIS, Grotius listed rules and discussed regulations of conflicts, which are regarded as the founding pillars of international law. Id. Among his observations was that punishment is necessary "to defend the honor or the authority of him who was hurt by the offence so that the failure to punish may not cause his degradation." Hannah ARENDT, Eichmann IN Jerusalem 287 (1964) (quoting Grotius). Philosophers and scholars continued to grapple with the rules of war. Jean-Jacques Rousseau posited that war was a relation between states rather than individuals, and that peaceable unarmed combatants should not experience the ravages of war:

War is not therefore a relationship between one man and another, but a relationship between one state and another. In war private individuals are enemies only incidentally: not as men or even as citizens, but as soldiers ....

... [S]inee the purpose of war is the destruction of the enemy state, one has the right to kill the defenders of that state so long as they bear arms. But as soon as they lay down their arms and surrender, they cease to be enemies.... They return to being simple men; and one no longer has a right to their lives.

Jean Jacques Rousseu, On the Social Contract (1762), reprinted in Basic Political Writings of Jean-Jaceues Rousseau 139, $145-46$ (Donald A. Cress trans., Hackett Publishing Co. 1987) (footnote omitted).

70. This was beeause there had never been a need to codify customary rules of law. But a new concept changed the boundaries of war and made codification necessary: the introduction of what Hans Morgenthau terms "total war," which was characterized by military mechanization, and the inclusion of the general populace into the overall aims and objectives of war. HaNS J. Morgenthau, Politics AMONG NATIONS 294 (1948). The end result was war for total stakes, where "a conquest once made is 
The first modern attempt to codify the laws of war was made by German scholar and Columbia law professor Francis Lieber in $1863,{ }^{71}$ and the first of a series of international conventions began with the ratification of the 1864 Geneva Convention for the Amelioration of the Condition of the Wounded in Armies in the Field, ${ }^{72}$ and the ratification of the Convention with Respect to the Laws and Customs of War on Land at The Hague in $1899 .^{73}$

With the advent of World War II, the nature and scope of warfare changed indelibly. A rough comparison of World War 1 and World War II shows that while the civilian to military death ratio in the first conflict was one to ten, the ratio shifted to one to one in the second conflict. ${ }^{74}$ Although the Allied side killed a significant number of civilians, even before World War II was over, there was recognition on the Allied side that the atrocious crimes committed by the Nazi regime needed to be addressed. Traditionally, the international community had exercised one of four options to respond to violations of international humanitarian Iaw: I) granting amnesty-pardoning all perpetrators; 2) establishing a truth commissioncreating an institutional body that would produce an accurate

made for good, from the point of view of the technological possibilities." Id. at 301. Total war cncompassed three components. Component one: war of total populations, where "individual citizens identify thcmselves fully with the wars in which their country is engaged." $I d$. at 289 . Component two: war by total populations, where all able-bodied men, and oftentimes women and children, are conscripted. Id. at 292. Component three: war against total populations, where everyone is a prospective participant and correspondingly, everyone becomes a prospective victim. Id. at 293 .

71. Abraham Lincoln authorized Lieber to devise a written code of conduct for the United States army, and he produced what is known as the "Lieber Code" (issued as General Orders 100 to Union troops). See Edoardo Greppi, The Evolution of Individual Criminal Responsibility Under International Law, INT'L REv. OF THE RED CROss, Mar. 9, 1999, at 531, http:/www.icrc.org/Web/eng/ siteeng0.nsf/iwpList74/911763EAA63170C0C1256B66005D85D0. Though the Lieber Code was only destined for American soldiers in combat, their influence was widespread. Among its provisions is a landmark stipulation in Article $\mathbf{4 4}$ of the Lieber Code requiring that "all wanton violence committed against persons in the invaded country... all robbery, all pillagc or sacking ... all rape, wounding maiming or killing of such inhabitants"' are punishable. Id.

72. Convention for the Amelioration of the Condition of the Wounded in Armies in the Field, Aug. 22, 1864, 22 Stat. 940. International humanitarian law was thus broken into two strains: the law of Geneva and the law of The Hague. The law of Geneva, stemming from the initial 1864 Red Cross convention, was designed to safeguard military personnel no longer engaged in combat, as well as civilians. ICRC, INTERnational Humanitarian LAw: ANSWERs to Your Questions, supra note 67. The law of The Haguc established the rights and regulations of armed combats, specifically limiting the "means of harming the enemy." Id. The adoption of the Additional Protocols of 1977 combined both branches and the separation no longer exists.

73. Convention (II) with Respect to the Laws and Customs of War on Land, opened for signature July 29, 1899, 32 Stat. 1803 (entered into force on Sept. 4, 1900). Among its provisions was the prohibition of the mistreatment of combatants, and the protection of civilians and civilian objects. Id. While the Convention was noteworthy in that it codified "generally accepted principles of customary international law," neither the means of enforcement nor the penalty for violations was stipulated. In other words, the Convention served merely as an international guideline, not as an enforceable mechanism that would ensure proper conduet in war. TAYLOR, supra note 65 , at 22-23.

74. Id. 
documentation of the abuses committed during a certain time period (epitomized by the South African Truth and Reconciliation Commission); 3) assisting in national investigations and prosecutions; and 4) on occasion, creating an international criminal tribunal to try the accused. ${ }^{75}$ In the case of Nuremberg, the allies assessed that because the Nazis were perpetrating crimes of such magnitude as to effectively exclude the first and second options, it would be necessary to establish an international justice tribunal. ${ }^{76}$ And so on October 18, 1945, the Nuremberg Tribunal officially commenced. ${ }^{77}$ Nuremberg paved the way for the ICRC to codify international humanitarian law, resulting in the 1949 Geneva Conventions. ${ }^{78}$

\section{Post-World War II Efforts to Codify International Humanitarian Principles}

This section will examine in greater detail post-World War II efforts to codify international humanitarian law principles. Three specific international humanitarian law instruments will be discussed: the 1948 Genocide Convention, the Geneva Conventions, and the suite of United Nations human rights conventions. These instruments are relevant to Kissinger in that they form the building blocks of the Rome Statute, the legal standard that will be used to assess Kissinger's conduct. In order to properly evaluate Kissinger, it is important to understand the manner in which contemporary international humanitarian law protections developed.

\section{a. The 1948 Genocide Convention}

Although the charge of genocide was not officially incorporated in the Nuremberg tribunal, it was used several times to describe the crimes committed by Hermann Goering, Rudolf Hess and others. ${ }^{79}$ Thereafter, a groundswell of support convinced the United Nations to declare genocide a

75. Virginia Morris \& Michael P. Scharf, The International Criminal Tribunal for RWANDA 691 (1998).

76. Id.

77. The actual proceedings and implications of Nuremberg will be discussed later in Part I.C.1.

78. Steven Ratner and Jason Abrams assert that Nuremberg pioneered three concepts. STEVEN $\mathbf{R}$ Ratner \& Jason S. Abrams, Accountability for Human Rights atrocities in International LAw 6-7 (2001). First, Nuremberg facilitated the establishment of the 1949 Geneva Conventions. Id. at 7. Second, Nuremberg was a "springboard" for the development of concurrent international human rights laws. Id. Third, Nuremberg laid the groundwork for further development and "elaboration" of international eriminal law, specifieally towards individual criminal responsibility. $I d$.

79. The term genocide was coined by Ralph Lemkin, a Jewish refugee from Poland teaehing in the United States, in 1944 in order to describe the Nazi Holocaust. William Schabas, United States Institute of Peace Special Report, The Genocide Convention at Fifty 2 (1999), available at http://www.usip.org/pubs/specialreports/sr990107.pdf. Lemkin combined the Greek word "genos" for clan, people or family, and the Latin word "oceidio," meaning total extinction or extermination. The result was "genocide," which he defined as the "intended and systematic 'genocidio;' that is, extermination of racial and national groups of civilian population in ctrtain territories in order to destroy certain races and layers of nations and peoples, racial and religious groups." WARREN Freedman, Genocide: A People's Will to Live 11-12 (1992). 
crime under international law carrying individual responsibility. ${ }^{80}$ On December 9, 1948, the United Nations General Assembly adopted the Convention for the Prevention and Punishment of the Crime of Genocide (Genocide Convention). ${ }^{81}$ The Genocide Convention entered into force on January 12, $1951 .^{82}$ It defines genocide in Article II as:

[A]ny of the following acts committed with intent to destroy, in whole or in part, a national, ethnical, racial or religious group, such as:

- Killing members of the group;

- Causing serious bodily or mental harm to members of the group;

- Deliberately inflicting on the group conditions of life calculated to bring about its physical destruction in whole or in part;

- Imposing measures to prevent births within the group;

Forcibly transferring children of the group to another group. ${ }^{83}$

Moreover, the Genocide Convention places an obligation on signatory parties to prevent and to punish genocide. ${ }^{84}$ Those charged with genocide are to be tried "by a competent tribunal of the State in the territory of which the act was committed" or "by such international penal tribunal as may have jurisdiction with respect to those Contracting Parties which shall have accepted its jurisdiction." 85

Scholars point to three significant limitations or inconsistencies with the provisions of the Genocide Convention. First, some scholars posit that genocide may be defined so narrowly as to exclude certain massacres that seem to fit into the category. For instance, there is some debate over how to classify the Cambodian genocide of 1975-79, where the Khmer Rouge killed an estimated 1.5 million people out of 7 million. ${ }^{86}$ Some would suggest that this is a case of "auto-genocide" rather than genocide, arguing that the convention only applies to the attempted extermination of a different national, racial, ethnic, or religious group. ${ }^{87}$ However, this interpretation tends to impute an element that does not exist within the written document of the Genocide Convention-the Convention never delineates that an event is classified as a genocide only if it takes place against a different group. Second, though the Convention attempts to assign an objective specification to what is and is not genocide, genocide is more often

\footnotetext{
80. G.A. Res. 96 (1), U.N. GAOR, 1st Sess., pt. 2 at 188-89, U.N. Doc. A/64/Add.1 (1946).

81. RATNER \& ABrams, supra note 78, at 25-26.

82. Id.

83. Convention on the Prevention and Punishment of the Crime of Genocide, Dec. 9, 1948, art.

11, 78 U.N.T.S. 277 [hereinafter Genocide Convention].

84. Id. at art. 111 .

85. Id. at art. V1.

86. Sydney Schanberg, Cambodia, in CRIMES of WAR, supra note 13, at 58-59.

87. Id.
} 
than not a crime of intent. The test is ultimately subjective: the real question is not "what is the result," but "what is the purpose of the offender." In the end, it is the perpetrator who defines and identifies a group for destruction.

But perhaps the Convention's most fundamental failure is that it has not been able to deter the recurrence of genocide. ${ }^{89}$ On the contrary, there have been more instances of genocide subsequent to the Convention than in the fifty years prior to its signing, culminating with the 1994 Rwandan genocide. ${ }^{90}$ Two particular reasons may account for this failure: 1) the obligations of the international community to intervene when faced with a potential instance of genocide are unclear, and 2) the international community has refrained from actively supporting the institutional development of ancillary bodies to the Convention. ${ }^{91}$ Nonetheless, the Genocide Convention has enjoyed some resurgence in recent years. The ICTY, ICTR, and ICC have incorporated its provisions into their respective charters. And in September 1998, the ICTR issued the first genocide conviction in history to Jean-Paul Akayesu. ${ }^{92}$

\section{b. The Geneva Conventions}

Following on the heels of the Genocide Convention, the Geneva Conventions were adopted on August 12, 1949 and entered into force on October 21, 1950.93 The International Committee of the Red Cross was responsible for their drafting; like the Genocide Convention, the Geneva Conventions were meant to respond to the horrific events of World War II. ${ }^{94}$ Together with the Additional Protocols of 1977, they form the major

88. SCHABAS, supra note 79 , at 4 .

89. See generally id. (criticizing the Convention for failing to stop continued instances of genocide).

90. See generally BEIGBEDER, supra note 11.

91. See Schabas, supra note 79. Regarding the first criticism, the international community is divided on whether the Convention legally mandates intervention to stop an identified occurrence of genocide. As William Schabas observes: "the issue is not whether the international community may intervene but rather whether it must intervene when a group protected by the Genocide Convention is threatened with extermination." Id. at 6-7. As for the second critique, Schabas points out that the intcrnational community has failed to establish basic supporting institutions for the Convention, such as an associated monitoring body that can immediately identify a potential situation of genocide, or a treaty body to define essential terms and assure proper implementation. Id. at 7 .

92. Prosecutor v. Akayesu, ICTR Case No. 1CTR-96-4-T, Judgment (Sept. 2, 1998), available at http://www.ictr.org/ENGLISH/cases/Akayesu/judgement/akay001.htm.

93. Geneva Convention for the Amelioration of the Condition of the Wounded and Sick in Armed Forces in the Field, Aug. 12, 1949, 75 U.N.T.S. 31; Geneva Convention for the Amelioration of the Condition of the Wounded, Sick and Shipwrecked Members of the Armed Forces at Sea, Aug. 12, 1949, 75 U.N.T.S. 85; Geneva Convention Relative to the Treatment of Prisoners of War, Aug. 12, 1949, 75 U.N.T.S. 135; Geneva Convention Relative to the Protection of Civilian Persons in Time of War, Aug. 12, 1949, 75 U.N.T.S. 287.

94. ICRC, supra note 67 at 11 . 
components of international humanitarian law. ${ }^{95}$ The Geneva Conventions are particularly noteworthy in that, as Neier notes, "[f]or the first time, explicit language designated certain acts as war crimes."96 Four Conventions make up the Geneva Conventions. ${ }^{97}$ Of particular interest to the Kissinger case is Convention IV, which specifically prohibits the following acts against civilians during war:

- Violence to life and person, in particular murder of all kinds, mutilation, cruel treatment and torture;

- Taking of hostages;

- Outrages upon personal dignity, in particular humiliating and degrading treatment;

- The passing of sentences and the carrying out of executionswith out previous judgment pronounced by a regularly constituted court, affording all the judicial guarantees which are recognized as indispensable by civilized peoples. ${ }^{98}$

At their core, the Geneva Conventions intend to protect persons in wartime who are no longer participating in the hostilities and to minimize harm resulting from conflict, such as displacement and the destruction of civilian property. ${ }^{99}$ Protected persons include both prisoners of war (i.e. former active participants) as well as civilians. Almost every state has ratified the Geneva Conventions, and they are considered to be universally binding in international law. ${ }^{100}$ Most commentators consider the Geneva Conventions to be a fairly mature set of rules, but potential challenges remain. These include determining whether traditional civilian structures, such as television and radio broadcasting stations, qualify for protection under the evolving Iandscape of modern warfare, and how to ensure actual application of codified rules. ${ }^{101}$

95. Id.

96. NEIER, supra note 69 , at 19 .

97. Convention I concerns the wounded and sick on land, Convention II covers the wounded and siek at sea, Convention III encompasses the trcatment of prisoners of war, and Convention IV offers protections of civilians in time of war. Protocols I and II of 1977 strengthen the protection of victims of international and non-international armed conflicts.

98. Convention (IV) Relative to the Protection of Civilian Persons in Time of War, Aug. 12, I949, 6 U.S.T. 3516.

99. See ICRC, International Humanitarian Law, at http://www.icrc.org/web/eng/siteeng0.nsf/ iwpList2/Humanitarian_law?OpenDocument (last visited May 29, 2004).

100. See MALANCZUK, supra note 57, at 344 (noting that while the Conventions technically only bind those who have signed them, because the Conventions state rules which are accepted as international customary law, they are universally binding).

101. See Jakob Kellenberger, Statements at the Twenty-Sixth Round Table on Current Problems of International Humanitairan Law, (May 9, 2002), available at http:/www.icrc.org/Web/eng/ siteeng0.nsf/iwpList99/EFC5A IC8D8DD70B9C1256C36002EFC1E. 


\section{c. United Nations Suite of Human Rights Conventions}

Motivated by the brutality of World War II, fifty countries came together in San Francisco and established the United Nations on October 24, I945. ${ }^{102}$ Bolstered by the precedents set forth in Nuremberg, the UN's first decade saw the organization promulgate a number of landmark international conventions and declarations. Foremost among these was the United Nations Declaration of Human Rights (hereinafter Universal Declaration), passed on December I0, 1948. ${ }^{103}$ It started out as an "articulation of shared values bearing moral weight on UN Member states." 104 It has developed into an essential building block of international law. Today, nine UN conventions, including the Universal Declaration and Genocide Convention, combine to form the core of the international human rights system. ${ }^{105}$ The United States has yet to ratify three of the nine treaties. ${ }^{106}$

Most relevant to the Kissinger case would be Article I of the Convention Against Torture; Articles 1, 6, 7, and 9 of the Covenant on Civil and Political Rights; and Articles 1 and 5 of the Covenant on Economic, Social and Cultural Rights. There is a strong argument, however, that because these three documents were all ratified or signed after Kissinger's relevant acts and would be applied retrospectively, they may not apply in an international court of justice. Having considered the development of international humanitarian law and international human rights law and established a theoretical basis for war crimes tribunals, the next

102. United Nations, supra note 14. The preamble to the UN Charter lists four general ideological aims of the organization: 1) to save succeeding generations from the scourge of war, which twice in our lifetime has brought untold sorrow to mankind; 2) to reaffirm faith in fundamental human rights, in the dignity and worth of the human person, in the equal rights of men and women and of nations large and small; 3) to establish conditions under which justice and respect for the obligations arising from treaties and other sources of international law can be maintained; and 4) to promote social progress and better standards of life. U.N. CHARTER pmbl.

103. Universal Declaration of Human Rights, G.A. res. 217(111), U.N. GAOR, 3d Sess., 183 plen. Mtg. at 71, U.N. Doc. A/810 (1948).

104. Universal Declaration of Human Rights, Overview: Drafting and Adoption, at http://www.udhr.org/history/default htm (last visited May 29, 2004).

105. These include the International Covenant on Economic, Social and Cultural Rights; International Covenant on Civil and Political Rights; International Convention on the Elimination of All Forms of Racial Discrimination; Convention on the Elimination of All Forms of Discrimination Against Women; Convention Against Torture and Other Cruel, Inhuman or Degrading Treatment or Punishment; Convention on the Rights of the Child; and the Convention Relating to the Status of Refugees.

106. The United States has yet to ratify the Covenant on Economic, Social and Cultural Rights; the Convention on the Elimination of All Forms of Discrimination Against Women; and the Convention on the Rights of the Child. It is important to note that ratification is distinguished from signing (which the United States has done for all nine conventions) in that ratification asserts consent to be bound in international law that the mere signing of a treaty does not. For a useful comparative chart detailing which countries have signed and/or ratified which UN human rights instruments, see Office of the United Nations High Commissioner for Human Rights, Status of Ratifications of the Principal International Human Rights Treaties, at http://www.unhchr.ch/pdf/report.pdf (last visited May 29, 2004). 
section will examine actual accountability mechanisms that have either shaped the collective way in which we view and prosecute war crimes (Nuremberg), or are currently operating and affecting international legal norms (ICTR, ICTY, ICC).

\section{The Development of International War Crimes Tribunals}

This section will look at the effect and influence of three different sets of war crimes tribunals: the Nuremberg Tribunal, the ICTY and ICTR, and the ICC. It will also examine the principle of universal jurisdiction as applied in the Pinochet case and the Alien Tort Claims Act. Sections 3, 4, and 5 , which describe the structure of the ICC, universal jurisdiction, and the Alien Tort Claims Act, are particularly relevant to our analysis of Kissinger's acts.

\section{Nuremberg Tribunal}

Without the Nuremberg Tribunal, it is unlikely we would even contemplate putting Kissinger in front of a war crimes tribunal. Nuremberg casts a long shadow on our collective consciousness that simultaneously prods and engulfs all succeeding efforts in international law. Perhaps Nuremberg is most important in a symbolic sense: it represents the first contemporary organized effort to hold political leaders and military officers accountable for their actions; it tackled one of the greatest human tragedies in modern history which arose from the largest armed conflict in history; and it commenced in 1945-before the dust had even settled on battlegrounds from Normandy to Stalingrad. ${ }^{107}$

The legal basis for trying individuals accused of war crimes is found in Article 6 of the International Military Tribunal Charter. ${ }^{108}$ It details three acts for which suspects can be tried: crimes against peace, ${ }^{109}$ war crimes, ${ }^{110}$

107. NeIER, supra note 69 , at 15 . A common misperception is that the Nuremberg tribunal was established to address the atrocities the Nazis perpetrated against the Jews. This was not its central purpose. As Judith Shklar notes, "Its real purpose was to try the Nazi leadcrs for having waged aggressive war." JUDITH N. SHKLAR, LEgalism 170 (1964). Nonetheless, the establishment of the Nuremberg tribunal was an achievement in itself. Instead of caving in to pressures to set up quick and efficient military courts that would execute masses of Germans, the Allies decided to pursue justice over vengeance.

108. Agreement for the Prosecution and Punishment of the Major War Criminals of the European Axis (London Agreement), Aug, 8, 1945, 82 U.N.T.S. 280, art. 6 (creating the International Military Tribunal Charter).

109. Crimcs against peace include "planning, preparation, initiation or waging of a war of aggression or a war in violations of international treaties, agreements or assurances, or participation in a common plan or conspiracy for the accomplishment of any of the foregoing." Id. at art. 6(a).

110. According to the Military Tribunal Charter, war crimes are:

[M] urder, ill-treatment or deportation to slave labour or for any other purpose of civilian population of or in occupied territory, murder or ill-treatment of prisoners of war or persons on the scas, killing of hostages, plunder of public or private property, wanton destruction of cities, towns or villages, or devastation not justified by military necessity.

Id. at art. 6(b). 
and crimes against humanity. ${ }^{111}$ The first charge, crimes against peace, which deals with jus ad bellum issues, is the most straightforward of the three. The other two charges, in the realm of jus in bello, encompassed new principles and actions on principles. They are more pertinent to the ICTY and ICTR; both tribunals have included the doctrine of crimes against humanity in their respective statutes. ${ }^{112}$

Nuremberg was the catalyst that expanded the reaches of international law, legitimized the field of international criminal law and led to international recognition that individuals, not merely states, are responsible for violations of human dignity and will be held accountable. ${ }^{113}$ At the same time, Nuremberg was not without its flaws. Many charged that it dispensed "victor's justice," and that the Allies were trying the Nazis for crimes for which they were equally guilty (especially in regard to the "war crimes" charge). Others felt that Nuremberg was applying ex post facto laws as it held individuals responsible for waging aggressive war for the first time in history (though it is important to note that Nuremberg did not set the principle of aggressive war, it was merely the first to act on it). ${ }^{114}$ Nonetheless, as Telford Taylor, one of the prosecutors at Nuremberg, wrote: "In terms of international law, the most important single feature of the Nuremberg trials was that the tribunals were established by international authority, and

111. According to the Military Tribunal Charter, crimes against humanity are:

[M] urder, extermination, enslavement, deportation, and other inhumane acts committed against any civilian population, before or during the war, or persecutions on political, raeial or religious grounds in execution of or in connection with any crime within the jurisdiction of the Tribunal, whether or not in violation of the domestic law of the country where perpetrated.

Id. at art. $6(\mathrm{c})$.

112. Its incarnation at Nuremberg represented the first time that "crimes against humanity were established in positive international law." M. Cherif Bassiouni, Crimes Against Humanity, in CrImEs of WAR, supra note 13, at 107. In certain respects, the concept of crimes against humanity overlaps with that of genocide and war crimes. But it is distinguishable from genocide because it does not require an intent to destroy a group "in whole or in part." Genocide Convention, supra note 83, at art. 11. And it is separate from war crimes because crimes against humanity does not apply only in times of war, but in peace as well.

113. The Nuremberg tribunal commenced on October 18, 1945. The tribunal consisted of a member from each of the four signatory countries: Britain, the United States, the Soviet Union and the provisional government of France. Twenty-two Nazi leaders were charged with the perpetration of one or several of the three listed acts. After 216 sessions, the tribunal closed a year later on October 1 , 1946. Three Nazi officials were acquitted, four were sentenced to terms between ten and twenty years, three were given life terms and twelve were sentenced to death and executed. War Crimes Trials, U.S. Holocaust Memorial Museum, at http://www.ushmm.org/wlc/article.php?lang=en\&Moduleld $=10005140$ (last visited Aug. 19, 2004).

114. NEIER, supra note 69 , at 16. In particular, many argue that the tribunal ignored the principles of nullum crimen sine lege (no crime without law) and nulla poena sine crimine (no penalty without crime). Id. In fact, while there was no binding written law regarding, for instance, aggressive war, the Nazis violated several established customary rules of eonduct, most of which were laid out in the 1899 Hague Convention on war. Finally, some criticized Nuremberg for limiting due process, specifically by disallowing appeals. See MorRIs \& SCHARF, supra note 75, at 14. 
exercised a jurisdiction internationally conferred."115 Indeed, Nuremberg shifted the setting of the laws of war-from the military courts of aggrieved nations, to an international tribunal whose decisions would affect the future direction of international law. ${ }^{116}$

\section{ICTY and ICTR}

After the Nuremberg and Tokyo Tribunals, ${ }^{117}$ no prosecutions before international tribunals occurred prior to the establishment of the ICTY and ICTR in 1993 and 1994, respectively. ${ }^{118}$ In response to evidence of horrendous war crimes in the Former Yugoslavia, the United Nations authorized the creation of the ICTY with Security Council Resolution 827 on May 25, 1993. ${ }^{119}$ As with Nuremberg, "the prosecutorial focus was on the individuals who committed the atrocities and engaged in genocide, not on groups or nation-states." 120

Similarly, in Rwanda, the United Nations authorized a special Commission of Experts after reports of carnage and killing on a massive scale began filtering out. The Commission revealed that not only had "[i]ndividuals from both sides to the armed conflict ... perpetrated crimes against humanity in Rwanda," but that "[a]cts of genocide against the Tutsi group were perpetrated by Hutu elements in a concerted, planned, systematic and methodical way," and that these acts "constitute genocide within the meaning of article II of the Convention on the Prevention and Punishment of the Crime of Genocide." 21 The Commission recommended that the individuals responsible for the genocide be brought to justice "before an independent and impartial international criminal tribunal."122 Indeed, the United Nations heeded the Commission's advice and on November 8, 1994, Security Council Resolution 955 authorized the establishment of the ICTR. ${ }^{123}$

115. TAYLOR, supra note 65 , at 80 .

116. The United States, under the leadership of General Douglas MacArthur, set up an "International Military Tribunal for the Far East" in the same time period to try alleged Japanese war criminals in a similar manner to their German counterparts. The Tokyo Tribunal used the same legal standard as the Nuremberg Charter: crimes against peace, crimes against humanity and war crimes. While the Tokyo Tribunal represented a continuing commitment to principles of individual criminal responsibility and wartime accountability, many criticize it (even in excess of Nuremberg) for its disproportionate American influence and claims of victor's justice. BEIGBEDER, supra note 11, at 4445.

117. See id.

118. RATNER \& ABRAMS, supra note 78, at 190.

119. Resolution 827, supra note 16.

120. Howard Ball, Prosecuting War Crimes and Genocide 121 (1999).

121. Report of the Secretary-General to the Security Council on Rwanda, U.N. Security Couneil, U.N. Doc s/1994/1125, available at http:/ods-dds-ny.un.org/doc/UNDOC/GEN/N94/381/91/PDF/ N9438191.pdf?OpenElement (last visited May 30, 2004).

122. Id.

123. Resolution 955 , supra note 17. 
For our purposes, the ICTY and ICTR are significant for two reasons. First, they reestablished international war crimes tribunals as viable mechanisms for bringing perpetrators to justice. As Theodor Meron noted about the ICTY: "Its creation portends at least some deterrence to future violations and gives a new lease on life to that part of international criminal law which applies to violations of humanitarian law. These are major, though obvious, achievements."124 Second, the tribunals lent sufficient momentum to engender the creation of a permanent tribunal, the ICC, which will directly assist our analysis of Kissinger's questionable acts.

\section{The International Criminal Court}

Amidst great fanfare worldwide (although only a lukewarm response in the United States), the ICC was created on July 1, 2002. ${ }^{125}$ Most regard its establishment as a tremendous achievement; one commentator referred to the ICC as "perhaps the most innovative and exciting development in international law since the creation of the United Nations."126 Its establishment reflects the ascent of humanitarian and human rights law from abstract theory to practical application. David Scheffer wrote, "With the end of the Cold War and the growing number of democracies and pluralistic societies committed to the advancement of human rights and the rule of law, it simply is no longer tenable...to tolerate impunity for the commission of such international crimes."127

Critics, however, question whether an institution "established by treaty and thus dependent on the voluntary consent of states can ever be effective." 128 The court intends to serve the needs and concerns of all states, yet its authorizing document is a treaty and not, for example, a UN Security Council Chapter VII resolution. ${ }^{129}$ This means that rather than render the ICC binding on all states, under normal circumstances its jurisdiction only extends to ratifying parties. ${ }^{130}$ This is especially troublesome when we consider the universal nature of the crimes encompassed under the Rome Statute, such as crimes against humanity and war crimes. On the other hand, it might have been nearly impossible to establish a court that states did not perceive as unduly infringing upon their sovereignty. "It was recognized from the outset that establishment through a multilateral

124. Theodor Meron, The Normative Impact on International Law of the International Tribunal for Former Yugoslavia, in WAR CRIMES IN INTERNATIONAL LAW 2I1, 212 (Yoram Dinstein \& Mala Tabory eds., 1996).

125. See Rome Statute of the International Criminal Court Overview, supra note 20.

126. SCHABAS, supra note 21 , at 20.

127. David J. Scheffer, Staying the Course with the International Criminal Court, 35 CoRNELL INT'L L.J. 47, 51 (2001-02) (footnote omitted).

128. Kristina Miskowiak, The international Criminal Court: Consent, Complementarity and CoOperation 9 (2000).

129. Id.

130. Id. 
convention was the only means that combined viability with legitimacy for the Court." ${ }^{\prime 131}$ Ultimately, we can best consider the ICC as comprising of a set of competing tensions: the need to attract a plurality of states to participate by including broad sovereignty guarantees and safeguards balanced against the necessity of establishing a legitimate tribunal that will effectuate the highest rule of law standards and preserve its long-term credibility. ${ }^{132}$

Historically, since the end of the Nuremberg Tribunal, the United Nations and the international community have debated the idea of a permanent international criminal court. ${ }^{133} \mathrm{~A}$ crucial initial question is why the international community decided to establish the ICC in I998, when efforts to bring about such an institution had been ongoing for fifty years. In response, we can point to a number of contributing factors: the "natural" course of history, critical momentum engendered by the ICTY and ICTR, and the end of the bi-polar Cold War framework which facilitated the entry of new multilateral institutions. ${ }^{134}$ As Adriaan Bos observed, "The end of the Cold War was a watershed. It transformed the climate in the United Nations to such an extent that the Security Council was able to reach agreement on the establishment of two ad hoc Tribunals." ${ }^{\prime 35}$ Essentially, these elements all had to synchronize for the ICC to emerge. First, a culture of acceptance regarding the rule of law had to develop. ${ }^{136}$ States had to become aware of what the rule of law entails and acquire a better understanding of its importance to global peace, stability and justice. The Nuremberg and Tokyo Tribunals were crucial milestones in this regard. Next, political exigencies had to coalesce in such a manner as to enable an environment suitable for the creation of the ICC. The paradigmatic shift away from the Cold War framework toward a multilateral environment fulfilled this condition. Finally, preliminary institutions needed to pioneer the concept of an all-encompassing criminal court; the UN needed to demonstrate that it was capable of setting up and running a criminal tribunal that was grounded in legitimacy and functionality. The ICTY and ICTR proved that the UN was up to the task. The result was the initiation of the Rome Conference as a final hurdle toward the ICC's establishment.

I31. Bruce Broomhall, International Justice and the International Criminal Court: BETWEen SovEREIGNTY AND THE RULE OF LAW 67-68 (2003) (footnote omitted).

132. Id.

133. See Kai Ambas, Establishing an International Criminal Court and an International Criminal Code-Observations from an International Criminal Law Viewpoint, EuROPEAN J. INT'L. L. (I996), at http://www.ejil.org/journal/Vol7/No4/art4.html (discussing historical efforts to establish an international criminal court).

134. Adriaan Bos, The International Criminal Court: Recent Developments, in REFLECTIONS ON The International Criminal Court 39 (Herman A.M. von Hebel et al. eds., 1999).

135. Id. at 42 .

136. By rule of law, this article describes the generalized acceptance and belief by a population in the legitimacy of a state's laws and its corresponding institutions. 
In June 1998, the UN convened the Diplomatic Conference of Plenipotentiaries on the Establishment of an International Criminal Court. ${ }^{137}$ Debates among the delegates from over I60 participating states were long and fierce and focused on several crucial issues. The issues included whether the Court's jurisdiction would be "automatic," or whether states could "opt" into the court's purview; how many states needed to ratify the Court's statute before it would begin operation; which crimes would be included under the Court's statute and how they would be defined; whether the prosecutor would have the power to initiate proceedings and what sort of checks and balances would govern prosecutorial discretion; what the Court's relationship vis-à-vis the UN Security Council would be; and whether the Court should include the death penalty. ${ }^{138}$

On July 17, 1998, after over a month of intense negotiation, the delegates finished drafting the Rome Statute. ${ }^{139}$ Almost four years later, the required sixty states had ratified the Rome Statute, and it entered into force on July I, 2002, officially establishing the ICC. ${ }^{140}$

This Comment asserts that despite its imperfections the Rome Statute represents a milestone achievement in international law and rights-based accountability. It institutionalizes the notion of international criminal justice, providing a permanent forum to direct complaints if other avenues of redress fail. From a cost-benefit perspective, it is much more straightforward and efficient to utilize the existing framework of the ICC to prosecute war crimes, rather than to petition the UN Security Council to set up a special ad hoc justice tribunal like the ICTY or ICTR. In fact, in the wake of the ICTY and ICTR, what has been described as "tribunal fatigue" seemed to have set in, where the inexorable process of hiring staff, selecting prosecutors, nominating judges, appropriating funds, and constructing courtrooms "turned out to be too time consuming and exhausting for the members of the Security Council to undertake on a repeated basis." ${ }^{141}$ From a deterrence viewpoint, because potential perpetrators know that an international court already exists that has the authority to prosecute violations of international humanitarian law, it might persuade a would-be Milosevic, for example, to reconsider a potentially violative course of action. Finally, from a systemic standpoint, the ICC represents the culmination of over fifty years of international law development, process, consensus-building, negotiation, and drafting. It is the logical next step for a world and body

137. See generally Rome Statute, supra note 6 (last visited June 5, 2004).

138. Philippe Kirsch, Q.C., Reflections on the International Criminal Court 2-3 (Herman A.M. von Hebel, Johan G. Lammers and Joline Schukking eds., 1999).

139. Schabas, supra note 21 , at 18.

140. United Nations, Multilateral Treaties Deposited with the Secretary-General, Rome Statute of the Intemational Criminal Court, at http://untreaty.un.org/ENGLISH/bible/englishintemetbible/partl/ chapterXVIII/treaty 10.asp (last visited May 30, 2004).

141. Scharf, supra note 22 , at 6 . 
politic that is becoming increasingly intertwined, but which remains volatile, unstable, and prone to abuse.

This Comment uses the stipulations of the Rome Statute as a legal framework in which to assess Kissinger's actions among the four allegations. Article 5 lists four crimes in which the ICC has jurisdiction: the crime of genocide, crimes against humanity, war crimes, and the crime of aggression. ${ }^{142}$ However, the crime of aggression has yet to be defined and ratified so only the first three crimes currently apply. ${ }^{143}$

In Article 6, the definition of genocide is borrowed verbatim from the Genocide Convention (arguably this definition has itself been enshrined as a jus cogens norm). ${ }^{144}$ It states: "For the purpose of this Statute, 'genocide' means any of the following acts committed with intent to destroy, in whole or in part, a national, ethnical, racial or religious group." ${ }^{\text {.145 }}$ It then lists a series of illustrative violations, such as "killing members of the group," or "deliberately inflicting on the group conditions of life calculated to bring about its physical destruction in whole or in part."146 This charge is probably least relevant to Kissinger, although as Part II discusses, one is accountable under the crime of genocide if he "directly and publicly incites others to commit genocide."147

Crimes against humanity and war crimes are defined similarly to their original incarnation in the Nuremberg Statute, but the Rome Statute has updated each to reflect developments in international criminal jurisprudence. ${ }^{148}$ Article 7 of the Rome Statute codifies crimes against humanity as "any of the following acts when committed as part of a widespread or systematic attack directed against any civilian population, with knowledge of the attack." ${ }^{49}$ The list of outlawed provisions includes murder, extermination, enslavement, deportation, imprisonment, torture, persecution against any identifiable group, enforced disappearances, the crime of apartheid, and "other inhumane acts of a similar character." 150

Finally, Article 8 defines war crimes as "[g]rave breaches of the Geneva Conventions of I2 August 1949." Specifically, "the following acts

142. Rome Statute, supra note 6 at art. 5 .

143. Id. As the official $1 \mathrm{CC}$ website notes, states could not agree on a uniform definition for the crime of aggression so it was left out and negotiations continue. Questions and Answers, ICC-CP1.int, at http://www.icc-cpi.int/ataglance/whatistheicc/faq.html (last visited Aug. 19, 2004).

144. Id. at art. 6 .

145. Id.

146. Id

147. Id. at art. 25 .

148. The legal basis for the Nuremberg Tribunal is found in Article 6 of the International Military Tribunal Charter. 1t details three acts for which suspects can be tried: crimes against peace, war crimes, and crimes against humanity. Nuremberg Trial Proceedings Vol. I, Charter of the International Military Tribunal, The Avalon Project at Yale Law School, 1996, at http://www.yale.edu/ lawweb/avalon/imt/proc/imtconst.htm\#art6.

149. Id. at art. 7.

I50. Id. 
against persons or property protected under the provisions of the relevant Geneva Convention" are war crimes: willful killing, torture, willfully causing great suffering, extensive destruction and appropriation of property not justified by military necessity, unlawful deportation and the taking of hostages. ${ }^{151}$ Article 8 defines further conduct warranting a war crimes charge: intentionally directing attacks against civilians, civilian objects, humanitarian assistance or peacekeeping missions; intentionally launching an attack with the knowledge that such an attack will cause loss of life or injury to civilians; or attacking or bombarding, by whatever means, towns, villages, and dwellings which are undefended. ${ }^{152}$ The charge of war crimes is perhaps most germane to Kissinger's situation, particularly the provision of intentionally directing attacks against civilians and civilian objects. ${ }^{153}$

Assuming national courts such as a U.S. court decline to exercise jurisdiction over Kissinger, theoretically it would be possible for the International Criminal Court to conduct a hearing on the subject-matter. ${ }^{154}$ The potential sticking point is that the United Stated has failed to ratify the Rome Statute, and has even taken the unprecedented step of "un-signing" its name from the Statute. ${ }^{155}$ This would seem to preclude a U.S. citizen from appearing before the court. The situation, however, is a bit more complicated. The Rome Statute is best understood as comprising two tracks. ${ }^{156}$ The first track constitutes situations in which the Security Council has referred a matter to the Court. This track creates a binding obligation on all states to comply pursuant to Chapter VII of the UN Charter. ${ }^{157}$ For example, if the Security Council agreed that potential violations of international humanitarian law had occurred in Liberia, it could authorize the ICC to pursue an investigation of that matter. The second track comprises situations referred to the Court either by individual countries or by the ICC Prosecutor. Unlike track one, this track "has no built-in process for enforcement," but instead relies on the good-faith cooperation of signatory

151. Id.

152. Id.

153. Part 11 discusses actual standards of individual criminal accountability, as written in the Rome Statutc, that determine whether a person is liable for one of the above crimes.

154. Not only do the purpose and structure of the ICC make it well suited to hear such a case, but the Rome Statute stipulates that the court's jurisdiction under the war crimes component extends to violations of the 1949 Geneva Conventions, mechanisms that were in place during Kissinger's service; that would seem to discount a potential Kissinger defense of retrospective justice. On the other hand, even if the Geneva Conventions wcre in place prior to Kissinger's service, no complementary structure akin to the ICC existed and it would seem to offend fundamental notions of justice to bring Kissinger to trial now that such a structure has comc into effect.

155. Peter Roff \& James Chapin, Faceoff: End of International Crime Court?, UPI (May 10, 2002) available at LEXIS.

156. Scharf, supra note 22 , at 6 .

157. Id. 
parties. ${ }^{158}$ As Scharf notes, "Most of the delegates in Rome recognized that the real power was in the first track." 159

Thus, under track one, it would be nearly impossible to bring Kissinger to bear for international humanitarian law violations without the consent of the United States due to the political realities of the Security Council (the United States wields a veto that would effectively preclude any unwanted action). It would be equally difficult to bring Kissinger before the ICC under track two without U.S. consent. While U.S. nonacceptance does not prevent the Court from exercising its jurisdiction and requesting Kissinger's presence, "the Court would have no power to oblige the United States to surrender the accused to the Court."160 A narrow exception may exist: if the accused is captured on the foreign territory of a state where the conduct in question has occurred, then this state may be obliged to surrender him at the request of the Court, even if the country of the accused demands otherwise. ${ }^{161}$ The relevant statute in question is Article 12(2) of the Rome Statute, which states:

In the case of article 13, paragraph (a) or (c), the Court may exercise its jurisdiction if one or more of the following States are Parties to this Statute or have accepted the jurisdiction of the Court in accordance with paragraph 3 :

(a) The State on the territory of which the conduct in question occurred or, if the crime was committed on board a vessel or aircraft, the State of registration of that vessel or aircraft;

(b) The State of which the person accused of the crime is a national. ${ }^{162}$

Depending upon the interpretation of the statute, one could read it as either stipulating the dual consent of the state on the territory of which the conduct in question occurred as well as the state of which the person accused of the crime is a national. Alternatively, one could view the statute as requiring that the state where the act occurred or the country of the accused provide consent. This distinction has decisive implications for Kissinger; under the second interpretation, if Kissinger was captured and detained in Cambodia, then the ICC could compel Kissinger to appear before the Court (because Cambodia is a ratifier of the Rome Statute), over the protests of the United States. Thus, while Kissinger is mostly protected from appearing before the ICC, a small layer of statutory ambiguity exists which could possibly compel his appearance.

Recently, the United States has taken substantive steps to ensure that potential U.S. suspects will escape the jurisdiction of the ICC. It has begun

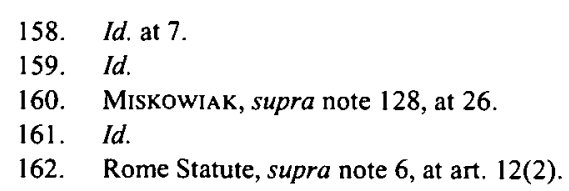


to implement so-called Article 98 Agreements. ${ }^{163}$ The Article 98 agreements are bilateral agreements between the United States and a particular country exempting U.S. citizens from the court's authority and authorizing countries to send a suspect back to the United States instead of to the ICC. ${ }^{164}$ At issue is Article 98(2) of the Rome Statute, which holds that the ICC "may not proceed with a request for surrender which would require the requested [s] tate to act inconsistently with its obligations under international agreements ...." 165 The Bush Administration has justified the bilateral agreements on the grounds that extraditing U.S. citizens would violate U.S. law, most notably the recently passed American Servicemembers' Protection Act. ${ }^{166}$ Most commentators, however, interpret Article 98(2) to apply only to existing Status of Forces Agreements-narrowly drawn agreements that apply only to military personnel-and not as a broad means to circumvent the entire Statute itself. ${ }^{167}$ As Amnesty International notes, Article 98(2) was introduced "to ensure that existing Status of Forces Agreements (SOFAs) were not nullified by the later in time Rome Statute. It was not designed as a license for impunity from the Court by letting states enter into subsequent bilateral agreements undermining the entire statutory scheme." 168 Thus far, the U.S. has had mixed success in persuading other states to sign the Article 98 agreements, despite an intense and somewhat coercive lobbying attempt. ${ }^{169}$ As of July 15, 2004, the U.S. State Department reported thirty-six signed agreements with fourteen state ratifications and forty-five public state refusals. ${ }^{170}$ For those countries that have ratified the Article 98 Agreement, a substantial legal bar has been raised against ICC jurisdiction over a U.S. civilian official such as Kissinger.

\section{Universal Jurisdiction}

Some posit that if an international justice tribunal like the ICC was unable to obtain jurisdiction over Kissinger, it would still be possible to bring Kissinger to a country like Belgium under principles of universal jurisdiction. The idea of universal jurisdiction was most notably propounded in the 1998 arrest and hearing of General Augusto Pinochet. Universal

163. Opposition Mounting to U.S. Arm-Twisting on ICC, Human Rights Watch (Aug. 13, 2002) at http://www.hrw.org/press/2002/08/article98press.htm.

164. Id.

165. Rome Statute, supra note 6, at art. 98(2).

166. Opposition Mounting to U.S. Arm-Twisting on ICC, supra note 163

167. International Criminal Court: U.S. Efforts to Obtain Impunity for Genocide, Crimes Against Humanity and War Crime, Amnesty International (Aug. 2002) at http://www.iccnow.org/documents/ otherissues/impunityart98/aiusimpunity200208.pdf.

168. Id. (footnote omitted).

169. Status of US Bilateral Immunity Agreements, Iccnow.org (July 15, 2004), at http:// www.iccnow.org/documents/otherissues/impunityart98/biasbyregion_current.pdf.

170. Id. 
jurisdiction is the notion that some crimes are of such international character and serious concern to the international community as a whole that any state may exercise jurisdiction over the perpetrator of such a crime, even if no other basis for jurisdiction exists. ${ }^{171}$ Generally, states accept that piracy, war crimes, genocide, and slave trading are universal jurisdiction crimes; debate surrounds whether certain acts of terrorism, assaults on diplomatic personnel, or kidnapping qualify under universal jurisdiction. ${ }^{172}$ U.S. courts first recognized the notion of universal jurisdiction in Filartiga $v$. Pena-Irala, where the Second Circuit declared: "Among the rights universally proclaimed by all nations, as we have noted, is the right to be free of physical torture. Indeed, for purposes of civil liability, the torturer has become-like the pirate and slave trader before him-hostis humani generis, an enemy of all mankind." 173

Thus, in the Pinochet case, the Law Lords (justices of the House of Lords, the United Kingdom's Supreme Court of Appeals) used universal jurisdiction as justification for annulling several asserted immunity defenses, including head-of-state immunity, noting that the 1984 Torture Convention created universal jurisdiction for the most serious of Pinochet's alleged transgressions. ${ }^{174}$ It is only in recent years that courts have begun to apply the concept of universal jurisdiction, and it is still in a process of definitional and jurisprudential refinement. ${ }^{175}$ Nonetheless, courts around the world, especially in Europe, are taking notice, and there are currently pending universal jurisdiction cases in France, Belgium, Germany, and Denmark. ${ }^{176}$

\section{Alien Tort Claims Act}

A final accountability option available to victims of Kissinger's actions would be a suit in U.S. federal court under the Alien Tort Claims Act (ATCA). Congress originally passed the ATCA as part of the Judiciary Act of 1789 , but it sat virtually unused for over two hundred years until Filartiga v. Pena-Irala revitalized the doctrine. ${ }^{177}$ Specifically, the ATCA provides: "The district courts shall have original jurisdiction of any civil action by an alien for a tort only, committed in violation of the law of

171. MaLANCZUK, supra note 57, at 113.

172. Id.

173. Filartiga v. Pena-Irala, 630 F.2d 876, 890 (2d Cir. 1980).

174. Michael P. Davis, Note, Accountability and World Leadership: Impugning Sovereign Immunity, 99 U. ILL. L. REv. 1357, 1368-70 (1999).

175. For a more in-depth discussion of the evolution and application of universal jurisdiction see Kenneth C. Randall, Universal Jurisdiction Under International Law, 66 TEx. L. Rev. 785 (1988).

176. See Peter Ford, Answering for Rights Crimes, Christian SCl. Monitor, Oct. 8, 1999, at 1. These cases include incidents involving the 1994 Rwanda Genocide, a Mauritian military torture incident, and violations stemming from the conflict in the former Yugoslavia. ld.

177. William Aceves, Affirming the Law of Nations in U.S. Courts: The Karadzic Litigation and the Yugoslav Conflict, 14 BerkeLEY J. INT'L L. 137 (1996). 
nations or a treaty of the United States." 178 Thus, for most human rights plaintiffs, the threshold question is whether they can prove a violation of "the law of nations." 179 The court in Filartiga found that the crime in question, torture, indeed fell within the bounds of a violation of the law of nations, and it awarded damages accordingly. ${ }^{180}$ Since Filartiga, U.S. courts have taken a step back from the doctrine amid a flurry of human rights litigation; federal courts have limited many cases on both political question grounds ${ }^{181}$ and lack of available remedy grounds. ${ }^{182}$ Nonetheless, human rights advocacy groups continue to bring cases, and on July 23, 2002, in Romagoza v. Garcia, a Florida district court jury awarded plaintiffs a record judgment of $\$ 54.6$ million for human rights violations undertaken by defendant generals in El Salvador. ${ }^{183}$

In conclusion, Part I attempted to provide a background to the major institutional actors that comprise the building-blocks of contemporary international criminal law. This includes the foundational cornerstone of Nuremberg, the newer tribunals represented by the ICTY, ICTR and the ICC, and alternative fora that integrate principles of universal jurisdiction, such as the U.S. Alien Tort Claims Act cases. Part II will present and examine individual accountability principles that underlie the aforementioned institutional actors and are the legal bases for any charges that may be brought against Kissinger.

\section{II}

\section{Individual AcCoUntability Principles}

This Part discusses individual accountability principles in two sections. First, it examines the standards outlined for individual criminal responsibility in the Rome Statute and as applied in the 200I ICTY case Prosecutor v. Kordic. ${ }^{184}$ Second, it examines the evolution and current incarnation of the command responsibility doctrine. These principles are useful because they provide the background for how we will determine

\footnotetext{
178. Filartiga, 630 F.2d at 880 (quoting 28 U.S.C. $\S 1350$ ).

179. Id.

180. Id.

181. The political question doctrine relates to the separation of powers principle and is the general idea that the judiciary branch should not resolve controversies between the political branches. The political question doctrine is usually not invoked for claims of U.S. nationals against the exccutive branch, but it is used to foreclose claims by foreign nationals against a U.S. executive.

182. See Marcia Coyle, Justices Weigh Alien Tort Act, NLJ.com (Mar. 29, 2004), at http://www.law.com/jsp/nlj/PubArticleNLJ.jsp?id=1080334938936.

183. Romagoza v. Garcia, No. 99-8634, slip op. (S.D. Fla. July 23, 2002). For more background on the Romagoza case see Center for Justice and Accountability, El Salvador: Carlos Eugenio Vides Casanova and Jose Guillermo Garcia, at http://www.cja.org/cases/romagoza.shtml (last visited May 30, 2004).
}

184. Prosecutor v. Kordic, ICTY Case No. IT-95-14/2, Judgment (Feb. 26, 2001). 
whether Kissinger should be held individually accountable in each of the four allegations.

\section{A. Individual Criminal Responsibility}

This section analyzes the doctrine of individual criminal responsibility in two parts. First, it presents and examines the individual accountability standards inscribed in the Rome Statute. Next, it looks at the manner in which the ICTY applied principles of individual criminal responsibility under the 200I case Prosecutor v. Kordic.

\section{The Rome Statute's Ascription of Individual Criminal Responsibility}

The Rome Statute's individual accountability standards come from a doctrine that has developed into a coherent body of law since the beginning of the twentieth century. Nuremberg was instrumental in assessing individual accountability for war crimes, crimes against humanity and crimes of aggression. The ICTY and ICTR incorporated many of Nuremberg's precedents, and the ICC continues that pattern by including an entire section-Article 25 of the Rome Statute-on individual criminal responsibility. Article 25 states that a person shall be "criminally responsible and liable for punishment for a crime" if that person:

(a) Commits such a crime ... ;

(b) Orders, solicits or induces the commission of such a crime which in fact occurs or is attempted;

(c) For the purpose of facilitating the commission of such a crime, aids, abets or otherwise assists in its commission or its attempted commission, including providing the means for its commission;

(d) In any other way contributes to the commission or attempted commission of such a crime by a group of persons acting with a common purpose ...;

(e) In respect of the crime of genocide, directly and publicly incites others to commit genocide;

(f) Attempts to commit such a crime by taking action that commences its execution by means of a substantial step, but the crime does not occur because of circumstances independent of the person's intentions. However, a person who abandons the effort to commit the crime or otherwise prevents the completion of the crime shall not be liable for punishment under this Statute for the attempt to commit that crime if that person completely and voluntarily gave up the criminal purpose. ${ }^{185}$

Sections (b), (c), (d), and (f) provide that soliciting, aiding, abetting, or otherwise contributing in the crime's commission is sufficient to bring about a war crimes charge. Because Kissinger never took a direct part in

185. Rome Statute, supra note 6, at art. 25. 
any of the alleged acts, but served more as the "mastermind" to the activities, it will be especially important to examine sections (b), (c), (d), and (f) in Part III. ${ }^{186}$

\section{Contemporary Application of Individual Criminal Responsibility: Prosecutor v. Kordic}

The ICTY decided Prosecutor v. Kordic on February 26, 200 I. ${ }^{187}$ The break-up of the Former Yugoslavia and the ethnic-based conflict that ensued provided the context for this case. In June 199I, the Republic of Croatia declared independence from the Former Yugoslavia, and in April 1992, Bosnia-Herzegovina followed suit. ${ }^{188}$ Within Bosnia, a substantial Croatian minority existed, and the community set up an alternative government - the "Croatian Community of Herceg-Bosna"-replete with an armed defense council. ${ }^{189}$ In August 1993, this community became the Croatian Republic of Herceg Bosna. ${ }^{190}$ Dario Kordic, the central defendant in the case, rose rapidly through the ranks to become president of the Croatian-Bosnian Republic in 1994. ${ }^{191}$ The indictment charged Kordic with criminal responsibility on the basis of his position as a superior to the perpetrators of the crimes alleged in the indictment. ${ }^{192}$ According to the $\mathrm{m}$ dictment, Kordic "planned, prepared, instigated, supported, directed, and engaged in a campaign of persecutions and ethnic cleansing, and committed serious violations of international humanitarian law against the Bosnian Muslim population...."193 The court ultimately found Kordic liable for "planning, preparing and ordering those parts of the campaign which fell within his sphere of authority," 194 which culminated in the massacre of hundreds of Bosnian Muslims between November I991 and March 1994. ${ }^{195}$ Kordic received a twenty-five year sentence from the court. ${ }^{196}$

Kordic offers several close parallels to the allegations against Kissinger. ${ }^{197}$ From the outset, the court delineates that Kordic was not a military commander but a civilian authority, and that he did not directly

\footnotetext{
186. See infra Parts III.B.1-4.

187. Prosecutor v. Kordic, 1CTY Case No. IT-95-14/2, Judgment (Feb. 26, 2001).

188. Id. at para. 5(a).

189. Id. at para. $5(\mathrm{c})$.

190. Id. at para. $5(\mathrm{~d})$.

191. Id.

192. Prosecutor v. Kordic, ICTY Case No. IT-95-14/2-PT, Judgment Annex V: Indictment, at para. 7.

193. Id.

194. Prosecutor v. Kordic, ICTY Case No. IT-95-14/2, Judgment, at para. 829.

195. Anton La Guardia, Croat Instigator of Ethnic Cleansing Given 25 Years, Dally TelegraPH, Feb. 27, 2001, available at www.globalpolicy.org/wldcourt/tribunal/2001/0227icty.htm.

196. Prosecutor v. Kordic, ICTY Case No. IT-95-14/2, Judgment, at para. 854.

197. See infra Part III.B.
} 
partake in the violence. ${ }^{198}$ Despite this fact, the court makes three significant points: planning is an "autonomous form of responsibility"; no formal superior-subordinate relationship is necessary for a finding of "ordering"; and that Kordic may not have been formally integrated in the military structure, but he was "associated" with the military leadership. ${ }^{199}$ In other words, the court held that a civilian leader who does not actually take part in acts of violence and who is not a formal member of a military organization can still be held liable for directed acts of violence if that civilian leader has a lead role in planning the attacks in question and enjoys at least an associational relationship with the implicated military. Because Kordic was one of the highest-ranking political leaders in the region, and because the prosecution was able to establish that Kordic planned and helped coordinate vicious attacks against the Bosnian Muslim population together with the military, the court held Kordic liable for war crimes. ${ }^{200}$

Kordic and Kissinger share numerous similarities. Like Kordic, Kissinger also operated in primarily a civilian context. However, in his capacity as National Security Advisor and Secretary of State, Kissinger arguably blurred the lines between thc civilian and military spheres even more than Kordic. Therefore, if we can ascertain that Kissinger "planned" any of the allegations in question, and that he was "associated" with the U.S. military, then it is possible to ascribe liability under principles of individual criminal responsibility, along the lines of Kordic.

\section{B. Command Responsibility Doctrine}

While less directly applicable to Kissinger than generalized individual criminal responsibility standards, it may also be possible to invoke the command responsibility doctrine toward the four allegations against Kissinger. First, this section briefly discusses the background and basic elements of the principle, which is rooted in the Supreme Court case In re Yamashita. ${ }^{201}$ Second, it looks at how Kordic applied the doctrine. ${ }^{202}$

\section{The Yamashita Standard}

The U.S. Supreme Court established the modern Iegal standard of command responsibility in In re Yamashita. ${ }^{203}$ The case concerned

198. The ICTY further notes: "While he played an important role in military matters, even at times issuing orders, and exercising authority over HVO forces, he was, and remained throughout the Indictment period, a eivilian, who was not part of the formal command strueture of the HVO." Prosecutor v. Kordic, ICTY Case No. IT-95-14/2, Judgment, at para. 839. HVO is the Croatian abbreviation for the Croatian Defense Council.

199. Id.

200. See id, at paras. 853-54.

201. In re Yamashita, 327 U.S. 1 (1946).

202. Prosecutor v. Kordie, ICTY Case No. IT-95-14/2, Judgment (Feb. 26, 2001).

203. 327 U.S. 1. 
atrocities committed by Japanese General Yamashita's troops in the waning days of World War II, specifically against the civilian population of the Philippines. Upon the unconditional surrender of Japan to the United States in 1945, the United States arrested Yamashita as a prisoner of war and a military commission charged him with violations of the law of war. ${ }^{204}$ The prosecution's basic argument was that the crimes committed by Yamashita's men were of such a "notorious" and "flagrant" nature that if Yamashita had made any effort whatsoever to meet the responsibilities of his command, he would have known of the abuses, and if he did not know, then it was "because he took affirmative action not to know." 205 In response, the Supreme Court defined command responsibility in the following manner:

It is evident that the conduct of military operations by troops whose excesses are unrestrained by the orders or efforts of their commander would almost certainly result in violations which it is the purpose of the law of war to prevent. Its purpose to protect civilian populations and prisoners of war from brutality would largely be defeated if the commander of an invading army could with impunity neglect to take reasonable measures for their protection. Hence the law of war presupposes that its violation is to be avoided through the control of the operations of war by commanders who are to some extent responsible for their subordinates. ${ }^{206}$

In other words, the Court held that a superior is generally responsible for a subordinate's actions, and if the superior knew or should have known of a subordinate's actions and did not take steps to prevent the acts from occurring or to punish those responsible, then the superior is liable under command responsibility. ${ }^{207}$ As we shall see, this is significant because Kissinger was not directly on the battlefield during the actions in question.

204. Yamashita was charged with having "unlawfully disregarded and failed to discharge his duty as commander to control the operations of the members of his command, permitting them to commit brutal atrocities and other high crimes against people of the United States and of its allies and dependencies, particularly the Philippines ...." Richard L. LaEl, The Yamashita Precedent: War CRIMES AND COMMAND RESPONSIBILITY 80 (1982) (citing the general comprehensive charge against Yamashita).

205. Id. at 83 (citing an argument against Yamashita). On December 7, 1945, the commission found that Yamashita "failed to provide effective control of [his] troops as was required by the circumstances," and it sentenced him to death by hanging. Id. at 95 . Yamashita appealed the decision to the Supreme Court, and the Court issued a writ of certiorari to hear the case. 327 U.S. 1.

206. Yamashita, 327 U.S. at 15 (emphasis added).

207. Therc are U.S. precedents that limit responsibility to the upper echelons. The most notorious is United States $v$. Calley, where the court held defendant William Calley, the ranking on-site officer at the My Lai massacre in Vietnam, liable for the killing of over five hundred civilians, but absolved his superior officer. 22 C.M.A. 534 (1973). However, unlike Yamashita, which was a recurring situation of war crimes, Calley is an isolated instance. Most significant, the command responsibility doctrine is codified in the 1956 U.S. Army Law of Land Warfare: it explicitly provides that a military commander is responsible for criminal acts if he has actual knowledge, or should have knowledge that troops or 
2. Contemporary Application of Command Responsibility: Prosecutor v. Kordic

Kordic represents one of the most recent international law applications of command responsibility. The prosecution charged him with criminal responsibility on the basis of his position as a superior to the perpetrators of the crimes alleged in the indictment. ${ }^{208}$ In an unexpected turn, the court at once affirmed the command responsibility doctrine, ${ }^{209}$ absolved Kordic from the charge, and cautioned that the doctrine should only be used with great care, especially with respect to civilians:

\begin{abstract}
Although liability under Article 7(3) may attach to civilians as well as military personnel, once it is established that the requisite power to prevent or punish exists, the [court] holds that great care must be taken in assessing the evidence to determine command responsibility in respect of civilians, lest an injustice is done. In the first place, it is established that substantial influence ... by itself, is not indicative of a sufficient degree of control for liability under Article 7(3). Secondly, while liability under Article 7(3) may attach not only to persons in formal positions of command, but also to those who are effectively in command of more informal structures, the [court] finds that Kordic lacked effective control ... defined as "a material ability to prevent or punish criminal conduct, however that control is exerciscd."210
\end{abstract}

The court found that "Kordic was neither a commander nor a superior in respect of the HVO (Croatian Defense Council), since he possessed neither the authority to prevent the crimes that were committed, nor to punish the perpetrators of those crimes."211 The reason why the court rendered Kordic liable under principles of individual criminal responsibility, but absolved him from liability under the command responsibility doctrine is that under the former principle, planning or helping to direct a violative act

other persons subject to his control are about to commit or have committed a war crime and he fails to take the necessary and reasonable steps to ensure compliance with the law of war or to punish violations thereof. Nicole Barrett, Note, Holding Individual Leaders Responsible for Violations of Customary International Law: The U.S. Bombardment of Cambodia and Laos, 32 Colum. Hum. RTS. L. REv. 429, 458 (2001).

208. Prosecutor v. Kordic, ICTY Case No. IT-95-14/2-PT, Judgment Annex V: Indictment, at para. 7.

209. The Command Responsibility Doctrine is eodified in the Article 7(3) of the Statute of the ICTY:

The fact that any of the acts referred to in articles 2 to 5 of the present Statute was committed by a subordinate does not relieve his superior of criminal responsibility if he knew or had reason to know that the subordinate was about to commit such acts or had done so and the superior failed to take the necessary and reasonable measures to prevent such acts or to punish the perpetrators thereof.

Statute of the Int'l Crim. Trib. for the Former Yugoslavia Art. 7(3) (Nov. 2003), available at http://www.un.org/icty/legaldoc/index.htm.

210. Prosecutor v. Kordic, ICTY Case No. IT-95-14/2, Judgment, at para. 840 (footnotes omitted).

211. Id. at para. 841 . 
is sufficient to establish culpability, whereas under the latter principle, the accused must actually be part of the military command structure and in a position to directly prevent or punish criminal conduct to be culpable. Applying this understanding to Kissinger's situation, the ICC must determine that Kissinger was part of the military chain of command and had the capacity to prevent the alleged acts in question for the command responsibility doctrine to take root. Part III aids us in this determination.

As a final note, the ICC has codified the command responsibility doctrine in Article 28 of the Rome Statute. It states that either a "military commander or person effectively acting as a military commander," or a non-military superior shall be criminally responsible for crimes "committed by subordinates under his or her effective authority and control, as a result of his or her failure to exercise control properly over such subordinates." 212 For the purposes of this paper, Article 28 is the governing standard for assessing liability against Kissinger under the command responsibility doctrine.

This concludes the background section on principles of individual accountability for war crimes and grave human rights violations. The next Part specifically examines where Kissinger's actions fall in this framework.

III.

\section{An Assessment of Whether Henry Kissinger Should Face a} HEARING For Violations of INTERNATIONAL HumanitaRian LAW

This Part presents the Kissinger analysis in three sections. First, it offers a brief background to Kissinger's realpolitik political philosophy, which is a guiding force behind many of his actions. Second, it presents and analyzes an aggregate list of allegations against Kissinger, collected from the research and writings of several different scholars, including Kissinger himself. ${ }^{213}$ It then assesses these allegations, count by count,

212. Rome Statute, supra note 6, at art. 28.

213. The following sources were used to compile the evidentiary record against Kissinger: NoAM ChomsKy, The BACKroom Boys (1973); Hersh, supra note 45; Hitchens, supra note 29; IsAACSON, supra note 31; M.V. KaMATh, Kissinger: The InCOMPlete Diplomat (1975); Kissinger, supra notc 53; Henry Kissinger, Does America Need a Foreign Policy? (2001); Henry Kissinger, White House Years (1979), Henry Kissinger, Years of Renewal (1999); Nautiyal, supra note 55; Henry Paolucci, Public Image, Private Interest: Kissinger's Foreign Policy Strategies in Vietnam (2002); William Shawcross, Sideshow: Kissinger, Nixon and the Destruction of CAMBodia (1979); John Hart Ely, The American War in Indochina, Part I: The (Troubled) Constitutionality of the War They Told US About, 42 STAN. L. REV. 877 (1990); John Hart Ely, The American War in Indochina, Part II: The Unconstitutionality of the War They Didn't Tell Us About, 42 Stan. L. Rev. 1093 (1990) [hereinafter Ely, The American War in Indochina, Part II]; Kopclman, supra note 56; Michael J. Kelly, Kissinger's World: A Cautionary Tale Through A Cold War Lens, 3 San Diego Int'L L.J. 133 (2002) (reviewing Henry Kissinger, Does America Need a Foreign Policy? (2001)); Barrett, supra note 207; Mark Hertsgaard, The Secret Life of Henry Kissinger; Minutes of a 1975 Meeting with Lawrence Eagleburger, ThE NATION (Oct. 29, 1990), available at http://www.etan.org/news/kissinger/secret.htm; Seymour M. Hersh, Kissinger and Nixon in the 
applying the international legal framework developed in Part I and the individual accountability principles in Part II. Third, it discusses potential defenses Kissinger can invoke, such as the act of state doctrine. Taken as a whole, these three sections demonstrate that, contrary to conventional wisdom, the legal burden that must be overcome in order to ascribe liability to Kissinger is exceedingly high and that only the first allegation, the secret bombing campaign, reaches the requisite evidentiary threshold.

\section{A. The List of Allegations Against Kissinger}

When presenting a count-by-count list of allegations against Kissinger, it is difficult to sort between the substantive and the frivolous. This Comment develops four specific allegations from comprehensively reviewing declassified government documents, legal and political writings, periodical articles, and Kissinger's own works. ${ }^{214}$ The four counts are:

1. Soliciting and commissioning "secret" bombing campaigns in neutral Laos and Cambodia, beginning in 1969, which were illegal under international humanitarian law, and which resulted in the death of at least one hundred thousand civilians.

2. Directly approving and assisting Pakistan in implementing mass civilian killings in Bangladesh in 1971.

3. Colluding and assisting with the 1970 assassination of General Rene Schneider of Chile, a country with which the United States was not at war.

White House, Atlantic Monthly, May 1982, at 35; Seymour M. Hersh, The Price of Power, Atlantic Monthly, Dec. 1982, at 21; various declassified primary documents accessed from the National Security Archive, available at http://www.gwu.edu/ nsarchiv (last visited May 30, 2004).

214. It is important to note that this bill of indictment omits two significant charges: involvement and approval of a 1974 coup and assassination attempt in Cyprus, and involvement in a plan to kidnap and murder a journalist living in Washington, D.C. This Comment has omitted these charges from consideration for several reasons. First, there is insufficient evidence available to even discuss these charges, let alone build a prima facie case of war crimes violations. These two crimes might also be overlooked because they pale in comparison to some of Kissinger's other purported atrocities, or because Kissinger may be less causally responsible for their occurrence than for the four listed counts. Regarding Cyprus, Hitchens attempts to build a case against Kissinger for collusion in an assassination attempt on a foreign head of state, in a fascist military coup, and in the murder and dispossession of thousands of civilians, but the presented evidence is flimsy and unsubstantiated. Hirchens, supra note 29, at 77-89. For instance, Hitchens concludes that because he can prove that Kissinger had foreknowledge of an impending coup in Cyprus and did nothing about it, that that is evidence for at least "passive approval." Hirchens, supra note 29 , at 84 . Perhaps that is the case, but that is insufficient grounds for a war crimes charge. Near the end of chapter seven, Hitchens notes, "[Kissinger's] attempts to keep the record sealed are significant in themselves; when the relevant files are opened they will form part of the longer bill of indictment." Id. at 87-88. Until those relevant files are opened, a sufficient basis does not exist to bring Kissinger to a tribunal on this charge. As for the Washington, D.C., kidnapping and murder charges, this appears to be outside the jurisdiction of a traditional war crimes tribunal-it occurred in the domestic country of the accused and is therefore the primary responsibility of the U.S. court system. It would be unprecedented (and outside the scope of this Comment) for an international tribunal to put Kissinger on trial for this count before a U.S. court. 
4. Enabling and approving mass civilian killings in East Timor by the Indonesian government in 1975.

The threshold question in our analysis is: under the Rome Statute, could a prima facie case of violations of international humanitarian law be made against Kissinger from the presented evidence? This Comment argues that such a prima facie case can be made on only one of the allegations: the "secret" Laotian and Cambodian bombing campaigns.

In assessing whether Kissinger should stand trial for each act in question, this Comment uses a three-part test. First, what is the causal connection between the act and Kissinger (i.e. did he directly order the act?), and is this causal connection strong enough to meet the standard of individual accountability established by Articles 25 and 28 of the Rome Statute (i.e. did Kissinger at least contribute to the commission of the crime)? Second, assuming we can prove causality, is the act itself indicative of a prima facie violation of international humanitarian law or international criminal law? The Comment will use Articles 5-8 of the Rome Statute as its governing standard for determining what constitutes a violation of international law (i.e. the act must fall into one of three categories: the crime of genocide, crimes against humanity, or war crimes). Third, what defenses can Kissinger bring in his support? Instead of presenting potential doctrinal defenses count by count, this paper discusses available defenses, such as the act of state doctrine, in the section immediately following the assessment of the four allegations.

\section{Allegation One: Responsibility and Culpability for "Secret" Bombing Campaigns in Neutral Laos and Cambodia, Beginning in 1969}

The United States recognized the neutrality of both Cambodia and Laos prior to the initiation of any bombing by the U.S. military. The United States was a party to the Geneva Accords of 1962, which outlawed the presence of foreign military personnel and forbade the introduction of arms and war materials into Laos, except for "conventional armaments... necessary for the national defense." 215 Likewise, the United States signed the 1954 Geneva Conference on Indochina that recognized Cambodia's neutrality and ordered the withdrawal of the Communist Viet Minh and Khmer Rouge to Hanoi. ${ }^{216}$ Nonetheless, in 1969, in response to General Creighton Abrams's (Commander of U.S. forces, Vietnam) request for B-52 bombing attacks on communist bases in Cambodia, the Nixon administration authorized Operation Breakfast, the first of many bombing sorties into Cambodia and Laos. ${ }^{217}$

215. Ely, The American War in Indochina, Part 1I, supra note 213, at 1094 (quoting 28 ConG. Q. WEEKLY REP. 1243 (1970)) (omission in original).

216. SHAwCRoss, supra note 213 , at 397.

217. Id. at 398 . 
Kissinger justified this "secret" bombing campaign, which Congress never authorized and which did not stem from an official declaration of war against Cambodia or Laos, in three ways. ${ }^{218}$ First, he argued that the communist North Vietnamese forces were using the two countries as safe havens and supply routes. ${ }^{219}$ Because the enemy was purportedly taking advantage of the neutrality of the two countries, Kissinger felt justified to expand the U.S. military theater of operations in response. As Kissinger noted:

After the Laos settlement of 1962, the North Vietnamese ignored their pledge to respect Laos's neutrality and opened a supply line (the Ho Chi Minh Trail) through Laos and Cambodia...they occupied the part of Cambodia along the South Vietnamese border and turned it into a military base area. After killing scores of Americans each month and inflicting casualties and destruction, they would return to Cambodia, brazenly using the neutral status of their unwilling host to legitimize their sanctuaries. ${ }^{220}$

Kissinger argued that, in fact, it was the North Vietnamese who violated international law, not the Americans: "A flagrant violation of international law became the cover for invoking international law to protect the bases."221 He concluded by angrily decrying the concepts of sovereignty and neutrality as a farce: "Amazingly, the Kennedy and Johnson Administrations which committed us to ground warfare in Indochina fell in with the charade that the killers of thousands of Americans would be protected by the technicality of operating from the sovereign soil of a neutral country."222

Second, Kissinger argues that Prince Sihanouk, the Cambodian head of state, had "all but invited these American attacks the year before...He implied he would ignore such attacks because the Cambodian population had been expelled by the North Vietnamese."223 Third, Kissinger points out that the "bombing was not even so secret," as journalists had repeatedly asked Sihanouk to comment on reports of American attacks. ${ }^{224}$

In response to Kissinger's justifications critics point out two crucial facts. First, whether or not Kissinger had ample justification for ordering the bombing and despite the fact that Sihanouk may have implicitly requested American intervention, United States' brazen violation of a fundamental international law principle, the doctrine of neutrality and sovereignty was unjustified. Quite simply, one cannot wage war

218. KISSINGER, YEARS OF RENEWAL, supra note 213, at 496-98.

219. Id. at 496-97.

220. Id.

221. Id. at 497.

222. Id.

223. Id.

224. Id. at 498 . 
indiscriminately, especially not against countries that have specifically stated their desire to remain neutral to ongoing violent conflict. Only if Sihanouk had officially requested U.S. intervention in his capacity as head of state would this rationalization bear scrutiny. Second, while the bombings may havc specifically targeted supply routes, because they resulted in such massive civilian death, they can properly be classified as indiscriminate. For instance, the Finnish Kampuchea Inquiry Commission estimates that out of a population of seven million, "six hundred thousand Cambodians died and over two million civilians became refugees as a result of the United States'[s] indiscriminate carpet bombing of towns, villages, jungle, and countryside from 1969 to April 1973." ${ }^{, 225}$ As for Laos, "[the] United States dropped more bombs on Laos than it did worldwide during World War II. By the end of the bombing in 1973, the U.S. had dropped 1.9 million metric tons of bombs ... making Laos the most heavily bombed nation per capita in history." ${ }^{226}$ Estimates of civilian deaths are in the range of $350,000.227$

Thus, Kissinger's justifications do not match reality. There may have been a realpolitik reason for the bombing, but the standard cost/benefit analysis of international law is quite different than Kissinger's. Under international law, the death of nearly one million civilians outweighs the American interest in severing supply lines.

The question then is whether there is a sufficient causal connection between Kissinger and the bombing campaign to support the finding of a violation-specifically, to what degree was Kissinger causally responsible for the bombing in Laos and Cambodia? Isaacson notes that Kissinger and Colonel Alexander Haig developed military and diplomatic scenarios for the Laos and Cambodia bombings, to the point of even discussing whether or not to acknowledge the operation if Cambodia "lodged a protest." 228 the end, Isaacson observed that the desire to keep the bombing secret, mainly from the American public, resulted in planning that proceeded "without full presidential participation," and without even the knowledge of Secretary of State William P. Rogers. ${ }^{229}$ Hitchens asserted that while Nixon bears ultimate responsibility for all decisions made during his presidency, "[Kissinger] was sometimes forced, and sometimes forced himself, into a position of virtual co-presidency where Indochina was concerned.",230 Finally, Noam Chomsky noted that Kissinger was a strong proponent of "tight central management in foreign policy," countering the notion that the

\footnotetext{
225. Barrett, supra note 207, at 437.

226. Id. at 434 (footnote omitted).

227. Id.

228. ISAACSON, supra note 31 , at 173.

229. Id.

230. Hitchens, supra note 29 , at 36 .
} 
government undertook foreign policy initiatives without Kissinger's knowledge or consent. ${ }^{231}$

If these arguments are supported, there appears to be sufficient causality to implicate Kissinger. As Article 25 of the Rome Statute states, an individual can be held accountable for ordering, soliciting, or inducing the commission of a crime, or even aiding, abetting, or otherwise assisting in the crime's commission. ${ }^{232}$ At the very least, Kissinger significantly aided and abetted the bombing campaign - and he admitted as much in his book, White House Years, when he noted Secretary of Defense Melvin Laird's reluctance to continue B-52 bombing: "One hour before the meeting [Secretary of State] Bill Rogers called to tell me that he was against using $\mathrm{B}-52 \mathrm{~s}$ in northern Laos and that he had Laird on his side." ${ }^{233}$ Despite the high-level dissent, Kissinger wrote that he advised Nixon to proceed with the bombing. ${ }^{234}$

Further, Kissinger may be held accountable under the command responsibility doctrine. As outlined in Article 28 of the Rome Statute, to be held liable, a superior must have had knowledge of the act, the act must have been within his control, and the superior must have failed to take all necessary and reasonable measures to prevent the act from taking place. ${ }^{235}$ As we have established, Kissinger definitively knew about the bombing campaign. And as he was one of the original architects of the bombing (along with Colonel Haig) and a proponent of continued bombing, the act appeared to be within his control. It is possible to counter-argue that Kissinger lacked exclusive control, at least officially, because he technically had to receive Nixon's authorization in order to proceed. Nonetheless, instead of taking all reasonable measures to prevent the bombings from occurring, Kissinger appeared to do everything in his power to assure their prolongation. Ultimately, Kissinger's liability under the command responsibility doctrine is not nearly as apparent as his culpability under Article 25. It is unclear whether Kissinger would be held accountable under this doctrine.

The second part of our analysis asks whether the bombing campaign itself is a prima facie violation of the Rome Statute. It appears that it is a war crimes violation in contravention of Article 8. As Article 8 states, it is

\footnotetext{
231. Сномsку, supra note 213 , at 32 .

232. Rome Statute, supra note 6, at art. 25.

233. KISSINGER, White House YeARS, supra note 213, at 452.

234. Kissinger explains:

1 recommended that the President authorize B-52 strikes if the enemy advanced beyond Muong Soui, the farthest point of Communist penetration [in Laos] before the government offensive of the previous summer. The President agreed. The Communists were beyond Muong Soui within twenty-four hours. An attack with three B-52s was launched on the evening of February 17-18.
}

Id. at 452-53.

235. Rome Statute, supra note 6, at art. 28. 
a violation of international law to intentionally direct attacks against a civilian population not taking direct part in hostilities or to intentionally launch an attack with the knowledge that such attack will causc incidental loss of life or injury to civilians. ${ }^{236}$ As documented above, the ordered bombings resulted in the death of over one million civilians in two officially neutral countries. Whether or not Kissinger possessed actual knowledge of the number of civilian deaths, as the architect of the bombings he should have had knowledge of the scale of killings. After all, we are not examining a situation where the U.S. military destroyed a single village with a discrete bombing run. Rather, we are looking at a protracted and intense bombing campaign that dropped more bombs per capita (in Laos) than any other in history. Further, whether the United States intentionally directed the bombs towards civilians, or whether it intended to drop bombs in a certain geographic area is beside the point-regardless of intent, the consequence was the massive and protracted killing of civilians otherwise uninvolved in the hostilities. In other words, because of the scale of bombings and the concurrent scale of civilian deaths, we can safely assert that Kissinger and the military should have known of the effects of their actions. Because these killings took place over a long period of time with the U.S. military and Kissinger's full knowledge, the deaths are evidence of prima facie war crimes violations. Thus, Kissinger would face a hearing under the first allegation. ${ }^{237}$

\section{Allegation Two: Direct Approval and Assistance to Pakistan in Implementing Mass Civilian Killings in Bangladesh in 1971.}

The second allegation contends that Kissinger and the United States definitively supported a post-election Pakistani military crackdown in Bangladesh that led to the deaths of between five hundred thousand and three million people. ${ }^{238}$ The initiating event of the India-Pakistan crisis of I971 occurred on March 25, 197I, when four American-built M24 tanks rolled in front of two student hostels of the University of Dacca, Bangladesh, and opened fire, killing 109 students upon the direct orders of GeneraI Yahya Khan, the Pakistani head of state. ${ }^{239}$ The situation in Bangladesh unraveled as the Pakistan military enforced a violent crackdown that killed some ten thousand people in three days, and eventually upwards of one million. ${ }^{240}$

236. Id. at art. 8.

237. According to William Shawcross, it could be argued that this use of air power constitutes a prima facie breach of international law, including the Charter of the International Military Tribunal used by the Nuremberg Tribunal. SHawcross, supra note 213, at 219.

238. See Hitchens, supra note 29 , at $44-54$ (describing the unfolding and implications of the Bangladesh tragedy).

239. M. V. KaMATH, supra note 213 , at 132-33.

240. IsAACSON, supra note 31 , at 372 . 
This count accuses Kissinger of not only deliberately ignoring reports of civilian massacre in Bangladesh akin to genocide, but also implicitly encouraging the continuation of such action for fear of alienating Yahyathe central go-between for a potential China-United States summit.

In order to fulfill the first criterion-establish a sufficient causal connection between Kissinger and the civilian slaughter in Bangladesh-it is first necessary to prove that Kissinger had actual knowledge of the unfolding massacres in Bangladesh. The U.S. government has recently declassified documents related to the crisis that establish Kissinger's actual knowledge. ${ }^{241}$ In an April 6, 1971 telegram originating from the U.S. Consulate in Dacca (known as the "Blood Telegram"), Consulate General Archer Blood and nineteen fellow diplomats dccried the U.S. policy of indifference as serving "neither our moral interests broadly defined nor our national interests narrowly defined." $242 \mathrm{He}$ declared:

We have chosen not to intervene, even morally, on the grounds that the Awami conflict, in which unfortunately the overworked term genocide is applicable, is [a] purely internal matter of a sovereign state ....We, as professional public servants, express our dissent with current policy and fervently hope that our true and lasting interests here can be defined and our policies redirected in order to salvage our nation's position as a moral leader of the free world. ${ }^{243}$

Instead of rethinking his position, Kissinger continued a hands-off policy toward Pakistan and even sent a message to Yahya Khan thanking him for his "delicacy and tact" at the height of the killings. ${ }^{244}$ In another communication, U.S. Ambassador to India Kenneth B. Keating cabled: "Am deeply shocked at massacre by Pakistani military in East Pakistan, appalled at possibility these atrocities are being committed with American equipment, and greatly concerned at United States vulnerability to damaging allegations of association with reign of military terror."245 It seems evident that Kissinger possessed actual knowledge of the events in Bangladesh and, moreover, that his colleagues in the field, including the Ambassador to India, were begging him to take action. As explained later, this

241. These documents are accessible from the National Seeurity Archive, which is located in George Washington University's Gelman Library in Washington, D.C., and has become "the world's largest nongovernmental library of declassified documents." National Security Archive, at http://www.gwu.edu/ nsarchiv/ (last visited May 30, 2004).

242. Confidential Telegram from the U.S. Consulate in Daeca, Bangladesh, to the U.S. Secretary of State regarding dissent from U.S. policy toward East Pakistan (Apr. 6, 197I), in The Tilt: The U.S. and the South Asian Crisis of 1971, National Security Archive Electronic Briefing Book No. 79 (Sajit Gandhi ed. 2002) [hereinafter NSA Eleetronic Briefing Book No. 79], at http://www.gwu.edu/ $\sim$ nsarchiv/NSAEBB/NSAEBB79/BEBB8.pdf.

243. Id

244. IsAACSON, supra note 31 , at 372.

245. Confidential Telegram from the U.S. Embassy in New Delhi, India, to the U.S. Secretary of State Regarding Seleetive Genocide (Mar. 29, 1971), in NSA Electronic Briefing Book No. 79, supra note 242, at http://www.gwu.edu/ nsarchiv/NSAEBB/NSAEBB79/BEBB3.pdf. 
knowledge alone does not establish a sufficient causal connection between Kissinger and the Bangladesh slaughter to warrant prosecution.

We must next determine whether Kissinger assisted with (i.e. aided and abetted) the events in Bangladesh. The record here is more ambiguous. Certainly, the Nixon administration was decidedly "tilted" against India and in favor of Pakistan. In a policy memorandum to President Nixon written in April 1971, at the height of the killings, Kissinger outlined various options for approaching the India-Pakistan crisis. Both men agreed that the administration should make "the most of the relationship with Yahya while engaging in a serious effort to move the situation toward conditions less damaging to US and Pakistani interests." ${ }^{246}$ Further, Nixon emphatically wrote on the memo: "To all hands: Don't squeeze Yahya at this time."247 Even more damaging is the revelation that the administration was militarily supporting the Pakistan regime throughout the crisis. The following telephone conversation between Kissinger and Nixon on December 4, 1971, is a good case in point:

[Kissinger]: We have an urgent appeal from Yahya. Says his military supplies have been cut off-in very bad shape. Would we help from Iran?

[Nixon]: Can we help?

[Kissinger]: I think if we tell the Iranians we will make it up . . . to them we can do it.

[Nixon]: If it is leaking have it denied. Have it done one step away. ${ }^{248}$

This conversation amply demonstrates that the administration's "tilt" towards Pakistan manifested itself in the form of actively supplying Pakistan with military armaments and goes a long way towards fulfilling the parameters of the second allegation.

However, in defense of Kissinger, three individual accountability issues stand in the way of a prima facie war crimes charge. First, while Kissinger heaped words of encouragement on Yahya during the height of the massacres, nothing he said explicitly sanctioned the continuation of the violence. As Article 25 notes, a person must at least contribute to the

246. Secret Memorandum from Henry Kissinger to the U.S. President Regarding Policy Options Toward Pakistan, in NSA Electronic Briefing Book No. 79, supra note 242, at http://www.gwu.edu/ nsarchiv/NSAEBB/NSAEBB79/BEBB9.pdf.

247. Id.

248. Confidential Transcript of Telephone Conversation Between Henry Kissinger and President Nixon on December 4, 1971, Prepared for Henry Kissinger (Jan. 19, 1972) [hereinafter Transcript], in NSA Electronic Briefing Book No. 79, supra note 242 (Apr. 28, 1971), at http://www.gwu.edu/ nsarchiv/NSAEBB/NSAEBB79/BEBB28.pdf. 
commission of a crime in order to be held liable. ${ }^{249}$ In this instance, Kissinger's actions fall short of "contribution." Second, while some may conclude that militarily supplying Pakistan during the height of the slaughter was akin to aiding and abetting genocide, the situation must also be examined with a wider lens: almost immediately, Pakistan found itself fighting a war on two fronts-an internal crackdown against the people of West Pakistan and Bangladesh, and an external war against India. One could just as easily argue that the U.S. administration intended to assist Pakistan in its external struggle against India, not with the military crackdown in Bangladesh. ${ }^{250}$ Thus, the military supply argument is also insufficient evidence of a war crimes violation.

Finally, there is a problem of causality especially in regard to Kissinger. Kissinger was indeed the day-to-day operational manager and policy advisor for Bangladesh, but as the above transcripts point out, it was Nixon who exercised ultimate authority. For example, it was Nixon who wrote-“[D]on't squeeze Yahya," and it was Nixon who ultimately decided to supply arms to Pakistan. Thus, it would be disingenuous on two fronts to hold Kissinger accountable under Allegation Two: because Nixon was the first-in-charge and carried ultimate authority, and because the final decision to kill Bangladeshi citizens lay with the Pakistani government, with Kissinger as a marginal participant. Condemnation of Kissinger stems not so much from what he did, but what he did not do-namely, condemn the killings and do everything in his power to stop their continuance. As of yet, Article 25 does not include a provision holding individuals accountable for lack of action. Because we cannot prove causality, there is no need to apply our analysis any further on this count.

3. Allegation Three: Colluding and Assisting with the 1970 Assassination of General Rene Schneider of Chile, a Country with which the United States Was Not at War.

Allegation Three encompasses the charge that Kissinger helped plan, assist, and finance the October 22, 1970, assassination of Chilean General Rene Schneider. When delving into the frenzied details of Kissinger's machinations in Chile, a world of covert operations, coup attempts, assassination hit squads, lies, deceit, betrayals, and bribery-seemingly borrowed from John Le Carré-emerges. In order to better understand Allegation Three, it is necessary to define several key terms. First, there is the " 40 Committee." As Kissinger describes it, the 40 Committee comprised of the Attorney General, the Deputy Secretaries of State and Defense, the Director of Central Intelligence, the Chairman of the Joint

249. Rome Statute, supra note 6, at art. 25. This Comment interprets Article 25(b) and (c) as encompassing the minimum standard of "contribute to."

250. See Transcript, supra note 248. 
Chiefs of Staff, and the Assistant to the President for National Security Affairs, who acted as chairman (this was Kissinger). ${ }^{251}$ All covert operations ran through the 40 Committee, which was "responsible for the dayto-day conduct of our national security affairs." 252 However, Kissinger was quick to point out that while the 40 Committee initiated operations with "full foreign policy review," thereafter it did not exercise day-to-day control of what it had approved. ${ }^{253}$

Kissinger was perhaps pointing out this discrepancy in order to absolve himself of guilt, but if he intends to use this as a defense, it is unlikely to succeed. As discussed above, the command responsibility doctrine would doubtless ascribe culpability to the 40 Committee and Kissinger. After all, the Yamashita standard and Article 28 of the Rome Statute mandate that if a superior knew or should have known of a subordinate's actions and did not take steps to prevent the acts from occurring or punish those responsible, then the superior is liable under command responsibility doctrine. ${ }^{254}$ Because the mandate of the 40 Committee was to exercise day-to-day responsibility over all national security affairs, and because Kissinger was the de facto head of the group, all regularly undertaken national security activities were under his purview, giving him ultimate authority and ultimate responsibility over them.

Furthermore, as Seymour Hersh notes, Kissinger repeatedly circumvented the 40 Committee on a number of CIA-directed operations in Chile: "In practice ... Kissinger and Nixon treated it [the 40 Committee] as they did the whole bureaucracy - as another office to be utilized or ignored at will."255 And the operations leading to Schneider's death were no exception: "Track II [CIA operation] was to be kept secret from [Ambassador] Korry, the State Department, and even the 40 Committee."256

This leads to the second set of key terms: Track I and II operations. Track I represented overt efforts to assist rival candidates financially and arose from the 1970 elections in Chile that first put President Salvador Allende in power. The administration opposed Allende's candidacy and viewed him as a compelling socialist threat to U.S. corporate interests in Chile, as well as general U.S. geopolitical interests in South America. Under Track I, the administration contributed \$2 million to assist Allende's rival candidates. When Track 1 failed, Nixon and Kissinger authorized Track II initiatives. As Kissinger euphemistically described it, Track II "turned into an attempt to encourage the Chilean military to support the

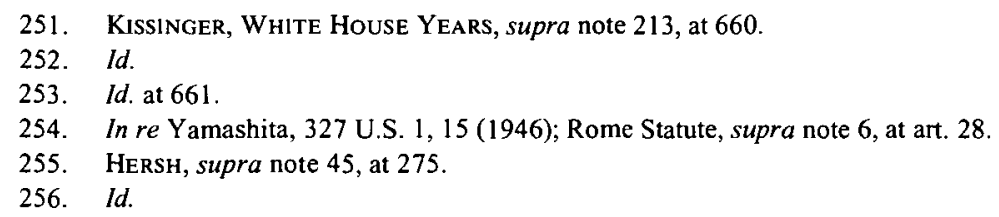


scenario of Track I."257 More explicitly, Track II would involve "a strategy of destabilization, kidnap and assassination, designed to provoke a military coup." 258 Thus, plans to violently overthrow Allende and install a more favorable government fell under Track II. Track II itself was so covert that it escaped the notice of the U.S. Ambassador to Chile, the State Department, and even the 40 Committee. In fact, the only parties who were aware of Track II efforts were Kissinger, Nixon, and the CIA. ${ }^{259}$

The essence of Allegation Three is that under Track II, Kissinger authorized the assassination of Chilean General Rene Schneider in 1970. In a Machiavellian cause-and-effect sequence (and another illustration of realpolitik at work), when Schneider refused to involve the military in Chile's civilian affairs, the United States targeted him to embolden the Chilean military to overthrow Allende. ${ }^{260}$ There is little doubt that the CIA (and the United States by implication) aided and abetted the murderers of Schneider right up to the killing itself. The following October I8, I970, transmission between CIA headquarters in Langley and its station in Santiago, Chile describes efforts to arm the would-be assassins:

Cooptee [CIA officer] met clandestinely evening 17 Oct with two Chilean Armed Forces Officers who told him their plans were moving along better than had thought possible. They asked that by evening 18 Oct Cooptee arrange furnish them with eight to ten tear gas grenades. Within 48 hours they need three 45 calibre machine guns ("grease guns") with 500 rounds ammo each. ${ }^{261}$

The greater question relevant to whether there is sufficient causality to hold Kissinger liable under the third allegation is whether Kissinger had knowledge of this operation. Kissinger claims that he turned off all Track II efforts on October 15, predating the above memo and purportedly absolving him of guilt for the October 22 assassination. ${ }^{262}$ Many assert that Kissinger's alibi was just a pretense, and that he was fully aware of continuing Track II efforts. ${ }^{263}$ As one CIA official wryly noted, "Kissinger and Nixon left us holding the bag, but that's what we're in business for. And if you don't like it, don't join up."264

\footnotetext{
257. KISSINGER, YeARS OF RENEWAL, supra note 213, at 315.

258. HitCHENS, supra note 29 , at 56.

259. ISAACSON, supra note 31 , at 290 .

260. Hitchens, supra note 29 , at 55-56.

26I. CIA Cable Transmission on Coup Plotting (Oct. 18, 1970), in Chile and the United States: Declassified Documents Relating to the Military Coup, September 11, 1973, National Security Archive Electronic Briefing Book No. 8 (Peter Kormbluh ed.), at http://www.gwu.edu/ nsarchiv/ NSAEBB/NSAEBB $8 / \mathrm{ch} 27-01 . \mathrm{htm}$.

262. ISAACSON, supra note 31 , at 310 .

263. Hersh, supra note 45, at 288; see also HITCHENS, supra note 29, at 64 (arguing that Kissinger's "paper-thin cover story" does not absolve him of liability for the assassination of Schneider).

264. HERSH, supra note 45 , at 288 .
} 
In response to international outrage, the Senate Intelligence Committee held hearings regarding the Schneider incident, but it concluded that because none of the supplied machine guns had been used in the assassination, and because the CIA had withdrawn its support of the assassins, there was "no evidence of a plan to kill Schneider or that United States officials specifically anticipated that Schneider would be shot during the abduction."265 As Article 25 of the Rome Statute states, "a person who abandons the effort to commit [a] crime... shall not be liable for punishment under this Statute for the attempt to commit that crime if that person completely and voluntarily gave up the criminal purpose."266 The record shows that, at least officially, Kissinger had called off the operation. Thus, while many feel that Kissinger and the CIA are covering up a greater role in the Schneider killing, the Senate Intelligence Committee has officially declared Kissinger and the CIA innocent of any direct wrongdoing, at least in their official capacities. Because there is no evidence beyond criminal intent (i.e. no act) linking Kissinger to the assassination, Allegation Three should be dropped.

\section{Allegation Four: Enabling and Approving Mass Civilian Killings in East Timor by the Indonesian Government in 1975.}

Allegation Four accuses Kissinger of enabling and encouraging the Indonesian government, led by General Suharto, to engage in mass civilian killings (some claim genocide) in East Timor in I975. The East Timor situation eerily parallels the earlier sequence of events in Bangladesh, but Kissinger's role in the East Timor crisis appears to be more explicit and causally linked than it was to the events that occurred in Bangladesh. The roots of the East Timor crisis originated in Portugal. In April 1974, a leftist military revolt overthrew Portugal's authoritarian government and set in motion decolonization efforts throughout its colonies, including East Timor. ${ }^{267}$ At first, the Indonesian government was receptive to East Timorese independence. ${ }^{268}$ Later, it changed its mind for fear that an enemy state would use East Timor as a base from which to launch aggressive operations against Indonesia. ${ }^{269}$ On December 7, 1975, Indonesian forces entered the former colony and engaged in mass civilian slaughter, killing upwards of one hundred thousand Timorese. ${ }^{270}$

\footnotetext{
265. Id. at 290.

266. Rome Statute, supra note 6, at art. 25(f).

267. East Timor Revisited, National Security Archive Electronic Briefing Book No. 62 (William Burr \& Michael L. Evans eds., 2001), at http://www.gwu.edu/ nsarchiv/NSAEBB/NSAEBB62 [hereinafter NSA Electronic Briefing Book No. 62].

268. Id.

269. Id.

270. Id. As Hitchens noted, "the violence required to impose [Indonesian military invasion] was so ruthless and generalized, that the figure of 100,000 deaths in the first wave-perhaps one-sixth of the entire population-is reckoned an understatement." Hitchens, supra note 29 , at 91 . In fact, the
} 
To begin our assessment of Kissinger's culpability under Allegation Four, we begin with our causality inquiry: determining whether Kissinger had actual knowledge of the events in East Timor. As the record shows, while Suharto had made independent plans to invade East Timor, he was also fearful of negative reaction in the West and delayed authorization of the invasion until he had received tacit approval from the United States. ${ }^{271}$ In fact, Suharto delayed any movement until he received explicit U.S. approval for the invasion. Kissinger and President Ford paid a visit to Indonesia on December 6, 1975, one day before the actual invasion. A text of the conversation between Suharto and the two American emissaries shows that Suharto sought explicit approval for "rapid or drastic action" in East Timor and Ford and Kissinger gave it to him:

[Suharto] I would like to speak to you, Mr. President, about another problem, Timor. . . .

... It is now important to determine what we can do to establish peace and order for the present and the future in the interest of the security of the area [and] Indonesia....We want your understanding if we deem it necessary to take rapid or drastic action.

[Ford] We will understand and will not press you on the issue. We understand the problem you have and the intentions you have. ${ }^{272}$

At this point, Kissinger interjects, not to protest this Faustian bargain that Ford has just assented to, but to cover their tracks at home:

[Kissinger] You appreciate that the use of US-made arms could create problems.

[Ford] We could have technical and legal problems ... .

violence was so pervasive and brutal that many have taken to describing the events of East Timor as genocide. Noam Chomsky compared East Timor to the Holocaust: "In the annals of crime of this terrible century, Indonesia's assault against East Timor ranks high, not only because of its scaleperhaps the greatest death toll relative to the population since the Holocaust-but because it would have been so easy to prevent, and to bring to an end at any time." Noam Chomsky, Introduction to Matthew Jardine, East Timor: Genocide in Paradise 7, 7 (1995). While this Comment hesitates to apply the label of genocide to East Timor for reasons of intent (it is arguable whether Indonesia intended to systematically exterminate every last Timorcse), certainly the events easily exceed the parameters of crimes against humanity and war crimes violations, as stated in Articles 7 and 8 of the Rome Statute.

27I. East Timor Revisited, supra note 267.

272. Telegram from the U.S. Embassy in Jakarta, Indonesia, to the U.S. Secretary of State memorandizing a meeting between President Ford and President Suharto on December 6, 1975, in NSA Electronic Briefing Book No. 62, supra note 267, at http://www.gwu.edu/ nsarchiv/ NSAEBB/NSAEBB62/doc4.pdf (emphasis added). 
[Kissinger] It depends on how we construe it; whether it is in self defense or is a foreign operation. It is important that whatever you do succeeds quickly. ${ }^{273}$

The above text is incredible for its clarity and bluntness. We are presented with a situation where a foreign head-of-state is explicitly asking the United States for permission to take drastic steps to end the selfdetermination pretensions of a smaII territory. In response, Ford indicates that not only does he "understand" Suharto's dilemma, but that he is aware of Suharto's "intentions." Further, the ever-prescient Kissinger does not question to what the United States has agreed. Rather, his concern is whether the use of U.S. supplied arms will create problems at home. Kissinger's advice to Suharto: perform your military operation and use the arms we have provided you in a quick and efficient manner.

The transcript above is a damning statement because it demonstrates that Kissinger knows that Indonesia will use U.S. supplied arms in a destructive manner - to an extent great enough to raise alarm bells at home. Kissinger is fully cognizant that when Suharto references "rapid or drastic action," he intends to pursue this action through the use of heavy military machinery. In reference to the above conversation, Kissinger has argued that he had no idea a tragedy of such magnitude would unfold:

At the airport as we were leaving, the Indonesians told us that they were going to occupy the Portuguese colony of Timor. To us that did not seem like a very significant event because the Indians had occupied the Portuguese colony of Goa ten years earlier and to us it looked like another process of decolonization. ${ }^{274}$

Either Kissinger is utterly confused or he is being dishonest. To claim that the proposed attack on East Timor did not seem significant begs the question: why was Kissinger so worried about the Indonesian use of American supplied arms? If the occupation was to be benign and routine, why did Kissinger raise such a fuss both at the initial meeting, and then subsequently on his return home? ${ }^{275}$ And how could Kissinger interpret "rapid and drastic action" as anything but military incited violence? The record demonstrates that not only did Kissinger possess actual knowledge of the events transpiring in East Timor during the crisis, but he possessed knowledge of the attacks prior to the invasion.

273. Id. (emphasis added).

274. Henry Kissinger, Remarks About his New Book (July 11, 1995) (transcript available at East Timor Action Network, Ask Kissinger About East Timor, at http://www.etan.org/news/kissinger/ ask.htm (last visited June 5, 2004)).

275. See Mark Hertsgaard, The Secret Life of Henry Kissinger: Minutes of a 1975 Meeting with Lawrence Eagleburger, THE NATION, Oct. 29, 1990, available at http:/www.etan.org/news/ kissinger/secret.htm (presenting released minutes of a meeting where Kissinger berated State Department officers for releasing a cable concluding that lndonesia's invasion of East Timor was in violation of international law). 
The next question is to what degree Kissinger assisted and encouraged the events in East Timor. Using the Article 25 standard of individual accountability, Kissinger must have aided, abetted, induced, or contributed to the commission of the act in order to be found liable. ${ }^{276}$ It does not appear that Kissinger's conduct meets Article 25's standard of accountability. First, it is debatable whether one can interpret Kissinger's statement to Suharto- "You appreciate that the use of US-made arms could create problems"- as sanctioning a decisive Indonesian military intervention that will most likely result in tremendous death and bloodshed. The link between Kissinger's statement and Suharto's subsequent actions in East Timor is tenuous. While Kissinger notoriously refrains from dissuading Suharto's invasion of East Timor, that is not equivalent to actively contributing to the commission of the act. The final decision to enter East Timor is Suharto's alone.

Second, some posit that further evidence of Kissinger's individual responsibility is found in a memorandum dated December 18, 1975, eleven days after the initial invasion of East Timor, and well after reports of brutal violence and civilian killing had been disseminated. In this memorandum of conversation, Kissinger instructs his staff (including Deputy Under Secretary Lawrence Eagleburger) to find a way to circumvent Congress and continue arms shipments to Indonesia:

[Kissinger] You have an obligation to the national interest. I don't care if we sell equipment to Indonesia or not. I get nothing from it. I get no rakeoff. But you have an obligation to figure out how to serve your country....

[Assistant Secretary of State Monroe Leigh] There's only one question. What do we say to Congress if we're asked?

[Kissinger] We cut it off while we are studying it. We intend to start again in January. ${ }^{277}$

In order to continue supplying arms to Indonesia without congressional interference, Kissinger devises a ploy where the administration will temporarily cut off weapons distribution to Indonesia, only to resume shipment less than three weeks later. Kissinger's actions in this regard are morally condemnable and the conversation is indicative of his realpolitik approach at its finest (or worst) hour, ${ }^{278}$ but it is not convincing evidence of

\footnotetext{
276. Rome Statute, supra note 6, at art. 25.

277. Hertsgaard, supra note 213 (quoting Memorandum of Conversation, Dec. 18, 1975).

278. As further demonstration of Kissinger's amoral outlook, some critics point to Kissinger's actions six months after the invasion, where he debates sending a representative to join an Indonesian government delegation that is officially visiting East Timor. He questions: "Am 1 wrong in assuming if we don't send somebody there will be some story out of it showing its disapproval of the United States action in regard to Timor?" Secret Transcript of State Department Staff Meeting (June 17, 1976), in NSA Electronic Briefing Book No. 62, supra note 267, at http://www.gwu.edu/ $\sim$ nsarchiv/NSAEBB/NSAEBB62/doc6.pdf. It is ironic that even at this late stage of the game,
} 
individual criminal responsibility under Article 25. Again, the link of causality between the military actions occurring in East Timor, the Indonesian superiors both in the field and in Jakarta and Kissinger are too remote to ascribe liability. It would stretch the definition of "contribute to the commission" to hold Kissinger accountable for the autonomous decisions and actions undertaken by a foreign state. ${ }^{279}$

Thus, despite the paper trail of evidence linking Kissinger to the Indonesian invasion of East Timor both prior to and during the action, Kissinger would not face a hearing before the ICC under Allegation Four. The link of causality is tenuous, and too many people with far greater culpability stand between Kissinger and the Timorese massacre. While Kissinger's conduct is condemnable, he was not the first, second, or even fifth line of authority when it came to controlling events in Indonesia. As with Allegation Two, our moral outrage stems more from what Kissinger failed to do-warn Suharto against precipitating the East Timor massacre and compel him to cease the violence during its commission-than what he did. Moreover, focusing exclusively on Kissinger ignores the basic command structure of the United States: the President is the commander in chief and bears ultimate responsibility for executive decision-making. Unlike Allegation One, where Kissinger largely kept Nixon in the dark regarding the Cambodian/Laos bombing campaign, Ford stood front and center with Kissinger and Suharto, one day before the commencement of the massacre. ${ }^{280}$

\section{Summary}

In summary, it appears that the most viable ground under which Kissinger would face liability at the ICC for violations of international humanitarian law would be under Allegation One, due to his assumed role as National Security Advisor in the bombing campaign in Laos and Cambodia. None of the other allegations are strong enough to bring Kissinger before the ICC because they lack causality. The next section will examine two defenses Kissinger could mvoke in response to the allegations leveled against him.

\footnotetext{
Kissinger's main preoccupation is with external media relations rather than with the mass human rights disaster occurring under his gaze.

279. Rome Statute, supra note 6, at art. 25.

280. The United Nations has established an East Timor Tribunal to investigate and prosecute "genocide, war crimes, crimes against humanity, murder, sexual offences, and torture." David Cohen, Seeking Justice on the Cheap: Is the East Timor Tribunal Really a Model for the Future?, Analysis from the East-West Center, Policy Brief No. 61 (2002), http://www.ciaonet.org/pbei/ewc/cod01/ cod01.pdf. However, the East Timor Tribunal's jurisdiction only runs from January 1 to October 25 , 1999 , thereby excluding the time period in which to hold Kissinger accountable. Id. Nonetheless, the establishment of such a tribunal is a positive step towards justice and will hopefully bring about further accountability in that tragic comer of the world.
} 


\section{B. Available Defenses for Kissinger}

This section will discuss two possible defenses Kissinger may be able to invoke: the act of state doctrine and recent jurisprudential retrenchment on the doctrine of universality. It will also present and discuss actual arguments Kissinger has put forth against universal jurisdiction and the ICC.

The act of state doctrine is closely related to, though distinct from, the concept of sovereign immunity. The doctrine applies on an individual level. Broadly speaking, under this doctrine, "the acts of a state, carried out within its own territory, cannot be challenged in the courts of other states." 281 According to extreme versions of this doctrine, acts of state are protected even if they contravene international law. ${ }^{282}$ The basic justification for the doctrine is largely related to comity and the fear that having the courts of one state judging the validity of another state's acts would likely imperil relations between governments and peace between nations. ${ }^{283}$ Thus, political questioning should stay in the realm of the executive. In the United States, this directly relates to the constitutional separation of powers doctrine. ${ }^{284}$ For Kissinger, this may be an effective doctrine to employ, especially in domestic courts. However, if he is served on the basis of universal jurisdiction, the act of state doctrine is less helpful.

As Professor Michael Byers points out, "Until recently, state immunity presented an almost insurmountable barrier to the effective enforcement of international human rights by national courts .... [T] idea that a former sovereign could be hauled up before the courts of another state and held accountable for gross violations of human rights was almost inconceivable."285 Of course, much of this thinking predated World War II and Nuremberg. Since that time, there has been a radical reconceptualization of the possibilities of international law within the global system. As demonstrated by the Pinochet case, the potential of universal jurisdiction seems boundless: "The Pinochet decision may further erode this doctrine [of sovereign immunity], making the immunity unavailable for certain types of criminal actions.".286

Democratic Republic of the Congo v. Belgium, ${ }^{287}$ a recent case at the International Court of Justice (ICJ), suggests that sovereign immunity and the act of state doctrine have not been pushed out the door quite yet. This

\footnotetext{
281. MaLANCZUK, supra note 57, at 122.

282. Id.

283. Id.

284. That is to say each of the government's three branches-legislative, judicial, executivehave defined roles outlined in the Constitution. By superceding the act of state doctrine, the United States risks loosening the rigid separation that is a hallmark of the American legal system.

285. Michael Byers, The Law and Politics of the Pinochet Case, 10 DuKE J. Comp. \& INT'L L. $415,418(2000)$.

286. Sison, supra note 23, at 1583 .

287. Arrest Warrant of 11 April 2000 (Congo v. Belg.), 2002 I.C.J. 121 (Feb. 14) [hereinafter Congo v. Belgium].
} 
case dealt with whether Belgium could bring Congo's Minister for Foreign Affairs, Abdoulaye Yerodia, to trial in its courts for alleged "crimes against humanity," relating to the 1994 Rwanda genocide. ${ }^{288}$ In a somewhat surprising decision, the ICJ denied Belgium's jurisdiction, stating that because Yerodia was an incumbent minister at the time of his arrest, sovereign immunity precludes him from having to stand trial in Belgium. ${ }^{289}$ In one sense, Congo v. Belgium has already had an immediate impact; it caused the Belgian Court of Appeals to dismiss the prosecution of Israeli Prime Minister Ariel Sharon for war crimes. ${ }^{290}$ Moreover, the court appears to reject customary international law and universal jurisdiction as a basis for trying alleged war criminals in national courts: "[it] does not acknowledge as legal the international prosecution of a former head of state where neither the state itself, nor the international community, has given leave for such prosecution." 291 This puts into serious doubts the precedential effect of Pinochet. ${ }^{292}$ The simple implication for Kissinger is that he may be able to fight on jurisdictional grounds the ability of a national court to prosecute him for war crimes.

In his recently published book, Does America Need a Foreign Policy?, Kissinger laid the framework for his deep opposition to both the principle of universal jurisdiction and the ICC. Kissinger only devotes fifteen odd pages (out of over three hundred pages) to the idea of universal jurisdiction, but that does not restrain his vehement hostility to the concept of universal jurisdiction from spilling out. ${ }^{293}$ He noted: "The world should think carefully about the implications of a procedure by which a single judge anywhere is able, essentially at his personal discretion, to assert jurisdiction over a citizen of another state for alleged crimes committed entirely in that other state ...".294 Further, he asserted that the doctrine of universalism, as applied in the Pinochet case "would arm any magistrate, anywhere in the world, with the unilatcral power to invoke a supranational concept of justice; to substitute his own judgment for the reconciliation procedures of even incontestably democratic societies where the alleged violations of human rights occurred."295

This is not an entirely fair critique. As discussed above, universalism can be thought of as a principle of last resort, to be invoked only when the

\footnotetext{
288. Id.

289. Congo v. Belgium, 2002 I.C.J. I21 at para. 71.

290. Rispin, supra note 25 .

291. Id. at $53 \mathrm{I}$.

292. Nonetheless, the court leaves intact the jurisdictional capabilities of "certain constituted international criminal courts, where they have jurisdiction," such as the International Criminal Tribunal for the Former Yugoslavia or the International Criminal Court. Congo v. Belgium, 2002 I.C.J. 12I at para. 61 .

293. Kissinger, Does America Need a Foreign Policy?, supra note 213.

294. Id. at 275-76.

295. Id. at 277 .
} 
national courts of the accused are either unwilling or unable to make the accused stand trial. Further, the accused's country has the option of refusing extradition, or if it genuinely believes the accused to be innocent of the alleged crimes, to try the accused in a national court under familiar domestic procedures. The essential concept to remember is that some crimes are so heinous and appalling in scope and nature as to offend universal sensibilities. As such, all states have a duty to investigate and prosecute the alleged perpetrators of these universal crimes; and if the national courts are not up to the task, then this undertaking should be entrusted to foreign courts.

On the ICC, Kissinger is no less harsh. He condemns the apparent widespread "discretion" entrusted to the ICC prosecutor, and he exhibits apprehension over the potential politicization of the ICC: "Definitions of the relevant crimes are vague and highly susceptible to politicized application.... [S]uch a procedure is likely to develop its own momentum without time limits and can turn into an instrument of political warfare."2296 It is ironic that Kissinger is decrying almost the identical war crimes standards that U.S. judges formulated and applied at Nuremberg and Tokyo. Further, the standards for war crimes, crimes against humanity, and genocide were not suddenly created for the express purpose of filling out the Rome Statute; rather international courts have been established and have developed these standards over time. In addition, these standards have been applied in innumerable settings, most recently (and successfully) at the ICTR and ICTY. It is true that every system has the potential for mishap and abuse, but this is no truer at the ICC than at any other muItilateral institution like the United Nations, World Bank, or European Union.

Finally, Kissinger complains about the potential politicization of justice at the ICC, but many would argue the opposite: that because the ICC's legal standard requires such a high evidentiary threshold, it enables Kissinger to get off on three of four charges-when many believe he should be held accountable on all four counts. The ultimate question that must be posed is whether it is preferable to exclude ourselves from the ICC for fear of abuse, or whether the prerogatives of international justice and accountability for war crimes should overcome the small potential for misuse. These are troubling issues and are difficult to resolve, but despite U.S. intransigence and detractors like Kissinger, world opinion appears to be moving decidedly in favor of the ICC model and towards the principle of universal jurisdiction.

296. Id. at 281. 
IV.

Broader Policy Implications Behind the International

\section{Criminal Court}

Now that we have reached the end of our inquiry into the culpability of Kissinger's actions under the four allegations, it is useful to take a step back and discuss what our application of the Rome Statute indicates about the strengths and weaknesses of the ICC. Part IV proceeds in two sections. The first section will discuss the reasons behind why a legal analysis of Kissinger tends to reduce his culpability. It will look at two specific aspects to the Rome Statute: whether the ICC's understanding of individual criminal responsibility is too narrowly focused, and whether the list of included crimes is too restrictive. The second section will build off the first section and will examine the broader policy implications arising from the scope and nature of the Rome Statute. Generally, this section contends that the analysis of Kissinger does not implicate the ICC as being particularly strong or weak; rather the Kissinger analysis is useful in that it gives us greater insight into the policy considerations that underlie and govern the functioning of the ICC.

\section{A. Reduction of Culpability Under the Legal Analysis}

To begin, it is important to note that the Rome Statute does not bring a whole new set of legal standards to the table - that is, the framers of the Statute did not create definitions of crimes of humanity or war crimes out of thin air. Rather, they carefully modeled the Rome Statute on preceding tribunals-Nuremberg, the ICTY, and the ICTR. The ICC thus represents the world's collective understanding of war crimes and individual criminal accountability as developed in the last fifty years. That is not to say that the Rome Statute does not contain modifications from prior tribunals. For example, the delegation from France demanded that the Rome Statute include a controversial provision where a signatory state may declare, up to a period of seven years from the date of accession, that "it does not accept the jurisdiction of the Court with respect to war crimes," when the alleged crime has been committed by its nationals or on its national territory. ${ }^{297}$

Overall, the modifications tend to be peripheral. In a historical sense, the ICC does not differ significantly from Nuremberg or the ICTY in the way in which it would assess the guilt or innocence of Kissinger. This renders the substantive nature of the Rome Statute less of an issue-it is difficult to argue with fifty years of collected institutional knowledge and developed scholarly thought.

Nonetheless, one overarching uncertainty comes to mind when reviewing our application of the Rome Statute to Kissinger's situation: why 
does the application of a legal standard reduce Kissinger's liability in direct contrast to conventional literature and wisdom? We can address this issue in two ways. In the first instance, we must inquire whether the Rome Statute's definition of individual criminal responsibility and its understanding of causality are too narrow. In Allegations Two (assistance to Pakistan to implement mass civilian killing) and Four (approving mass civilian killings in East Timor), the main impediment between Kissinger and the docket of the ICC was that his conduct did not meet the causality requirement of Article 25, which requires him to "contribute[] to the commission or attempted commission of," "aid[], abet[], or otherwise assist[]," or solicit the particular crime in question. ${ }^{298}$ Many would argue that either this is too narrow an understanding of causality, or that our interpretation of this provision is too confined. In response, it may be the case that Article 25's wording is too restrictive and excludes a high proportion of perpetrators who otherwise would face liability under the Rome Statute. However, substantial justifications exist for keeping Article 25's definition narrow; this will be discussed in further detail below. Moreover, as for the contention that this interpretation of Article 25 is too confined, it must be noted that the history and jurisprudence of contemporary war crimes tribunals has yet to record an instance where a foreign national was found guilty of assisting with the commission of war crimes in an alternate country. This may be the logical next step for future international criminal tribunals. At present, such a holding is unprecedented and advocating on its behalf is beyond the scope of this Comment. ${ }^{299}$

The second manner in which we can address the issue of why Kissinger seems to avoid culpability under a legal analysis is to inquire whether the types of crimes included in the Rome Statute are too limited in scope, definition, and reach. As discussed above, the Rome Statute currently includes four categories of crimes: war crimes, genocide, crimes against humanity, and crimes of aggression (which is still undefined). The listed crimes are not small in scale by any means - they are targeted toward the highest-ranking killers and encompass the worst perpetrations possible

298. Rome Statute, supra note 6, at art. 25.

299. A final critique of Article 25 is that it fails to suffieiently aecount for inaction as an element of eriminal responsibility. This was a central point of debate among the Rome delegates. As Darryl Robinson writes regarding the crimes against humanity stipulation (Article 7):

The action/inaction issue was perhaps the most controversial and difficult issue.... [T] he action requirement was included to address the concern that a policy (and therefore an 'attack') should not be inferred simply form a State's failure to act, where there may be innocent reasons for the inaction and where there is in fact no underlying poliey to encourage crimes.

Darryl Robinson, The Context of Crimes Against Humanity, in The International Criminal Court: Elements of Crimes and Rules of Procedure and Evidence 61, 74 (Roy S. Lee ed., 2001). Robinson notes that eventually the negotiators agreed to include a fairly strong action requirement in the text, but that they footnoted an exception which addressed inaction, clarifying that in "exceptional circumstances, deliberate failure to take action" will constitute a violation. $I d$. at 76 . 
to humanity. Moreover, these crimes are not meant to apply to isolated individuals working autonomously; rather, one of the primary stipulations of Article 7 (concerning crimes against humanity), for example, is that the acts are committed "as part of a widespread or systematic attack." ${ }^{300}$ In other words, not only must a certain type of crime be committed (i.e. murder, extermination, or enslavement), but this crime must occur within the larger context of systemized, organized behavior ${ }^{301}$ Thus, it seems that our assessment of the ICC should shift focus, with more of an emphasis on the broader policy rationales behind the ICC and war crimes tribunals generally. This next section will examine the policy implications of the Rome Statute.

\section{B. Policy Implications of the Rome Statute}

An important set of questions that must be asked when examining the ICC is: What is the role and purpose of the ICC? To whom (what type of perpetrators) is it directed? Is the ICC meant to try only the highest-ranking officials (the track record of Nuremberg and the ICTY and ICTR would seem to point in that direction), or should it encompass a broader stratum of perpetrators? Quite simply, under a narrow understanding - i.e. try only the highest-ranking perpetrators - it would be an inconsistent application of justice to hold Kissinger accountable for any acts but those charged in the first allegation because in the other instances he was strictly subordinate to Presidents Nixon and Ford, and maybe to others as well. Historically, lawmakers created tribunals like Nuremberg in order to try the "biggest fish." Out of all the Nazi officials captured and held by Allied forces, Nuremberg put only the tiniest fraction of them on trial, twenty-four in totaI. Likewise, through the beginning of 2004 the ICTR had only handed out eight convictions. ${ }^{302}$ The question then becomes: what is the underlying rationale behind the "big fish" theory of justice?

On one level, it is a resource issue. Quite simply, the budget does not exist for the ICC to handle more than a handful of cases per year. In a world of limited resources, it does not make practical or moral sense to focus the bulk of international foreign assistance assets on criminal justice proceedings. Often, these appropriations resemble a zero-sum game, where a $\$ 30$ million allocation to the ICTR entails a $\$ 15$ million deduction from a democratic governance assistance program.

On another level, we must consider the symbolic and deterrence value of trying the highest-ranking perpetrators before well-publicized, wellfunded, functionaI tribunals. Gustavo Gallón notes:

\footnotetext{
300. Rome Statute, supra note 6, at art. 7.

301. See id.

302. Coalition for International Justice, Indictees-1CTR, at http://www.cij.org/ index.cfm?fuseaction $=$ indictees\&tribunallD $=2$ (last updated Aug. 16, 2002).
} 
There is a general consensus on the need for an international court to focus exclusively on very serious crimes that are not prosecuted by domestic courts .... The international criminal court need not prosecute every crime committed in the world, but only those heinous crimes of genocide, crimes of war, crimes against humanity, and eventually crimes of aggression, that escape the jurisdiction of domestic tribunals. ${ }^{303}$

When we narrow our emphasis to a few top perpetrators, we also tend to direct greater world attention toward their specific acts and crimes. Rather than bury a Milosevic among a slew of lower-level perpetrators, it is important that we recognize the significance of their actions and treat them accordingly.

That is not to say that the ICC does not exhibit serious structural flaws. Criticisms range from suggestions of Security Council political meddling ${ }^{304}$; assertions that the Rome Statute does not adequately address victims' needs ${ }^{305}$; and claims that the Rome Statute omits certain crimes of war. ${ }^{306}$ Nonetheless, the Rome Statute is a functional doctrine that borrows from an impressive list of prior, successful tribunals. It is due more to design than weakness that the ICC would only try Kissinger on one of the four allegations. In a world of finite resources and an exploding number of conflicts, this may be the best the ICC can do for the near future.

\section{ConClusion}

This Comment selected Kissinger as the subject for several reasons: lingering controversy and debate over his past actions; his continued prominence in the political arena; and the wide scope of allegations leveled against his person, which allows us to more fully assess the applicability of the Rome Statute in a variety of circumstances. In many ways, it appears that a legal analysis of Kissinger's past actions raises as many questions as it answers. Doubtlessly, his critics will continue to maintain that he should face a tribunal on all counts, while others will argue that putting a highlevel U.S. official before an international body of justice sets a dangerous precedent of diminished sovereignty. Nonetheless, this Comment contends

303. Gustavo Gallón, The International Criminal Court and the Challenge of Deterrence, in International Crimes, Peace, and Human Rights 100 (Dinah Shelton ed., 2000).

304. Nabil Elaraby observes: "[The 1CC's] independence and power can only be guaranteed when its proceedings are clearly beyond the scope of the political influence of the Security Council. Regrettably the Statute provides an open invitation to the Council to affect and even to dominate the proceedings." Nabil Elaraby, The Role of the Security Council and the Independence of the International Criminal Court: Some Reflections, in The Rome Statute of the International Criminal Court: A Challenge to Impunity 43, 46-47 (Mauro Politi \& Giuseppe Nesi eds., 2001).

305. See Madeline Morris, Complementarity and Its Discontents: States, Victims, and the International Criminal Court, in International Crimes, Peace, and Human Rights, supra note 303 , at 177.

306. Gallón, supra note 303 , at 102. 
that the only way to bring about a genuine notion of political accountability is to use existing legal procedures within a legitimate and universally recognized institutional framework. For better or worse, the International Criminal Court seems to fit these parameters-a plurality of countries around the world recognizes its jurisdiction.

The objective of this Comment is not to render a normative judgment of whether Kissinger should actually face a tribunal of judges at some point in the future. Rather, it inquires whether the allegations against Kissinger reach a certain threshold, sufficient to qualify for a hearing at such a tribunaI. After examining each of the four allegations under the legal standard established by the Rome Statute, this Comment concludes that Kissinger's conduct only reaches the threshold of a prima facie violation of international humanitarian law in one of the four instances-for the bombing campaign in Cambodia and Laos. As this Comment has noted, this runs contrary to conventional wisdom, which tends to hold Kissinger as the primary culprit and instigator in all four of the presented situations. This Comment is not meant as a rebuttal to this collected knowledge; its significance is that it utilizes an impersonal procedure-a legal test-as a means to assess Kissinger's conduct. It is important to note that law is only one of several ways in which to assess accountability, and oftentimes it is an imperfect mechanism, at best. Kissinger may elude substantial legal culpability for his actions but this does not mean he is not guilty of violating human rights norms or collective notions of morality and fair play. However, such an assessment is outside the scope of this Comment.

As a side note, it is anyone's guess whether Kissinger will ever be held accountable for his actions, and if so, where he will be tried. The court of first resort would be a U.S. federal court but it does not appear likely that the government will consent anytime soon to "trying one of their own." It is worth mentioning that alleged victims of Kissinger's policies may still be able to seek civil damages from Kissinger under the aegis of the Alien Tort Claims Act, but bringing a case against such a high-level U.S. official is unprecedented and has a small chance of success. The obvious alternative forum is the International Criminal Court. Because the United States refuses to accede to the Rome Statute, it would be difficult to have Kissinger stand trial at that forum. If a strong enough case can be built against Kissinger, then it would be possible to bring him before the ICC even without U.S. ratification-after all, it is within the UN Security Council's prerogative to force Kissinger to stand trial under the principle of universal jurisdiction. ${ }^{307}$ Nonetheless, the ICC's statute itself proscribes jurisdiction for crimes committed prior to 2002, making a trial an unlikely possibility. Otherwise, the only other possibility for Kissinger to face a hearing would be for a country like Belgium, which has attempted to

307. Bassiouni, supra note 112 , at 813 . 
exercise universal jurisdiction in the past, to invoke universal jurisdiction against Kissinger and hope that the United States decides not to interfere.

There is also a fairness issue over whether Kissinger should face a war crimes tribunal at all. While Kissinger wielded an enormous amount of power, he was never the highest superior within any of the allegations. "The buck stops here," President Truman famously declared, asserting that full responsibility ultimately resides with presidents, and not necessarily with their subordinates. ${ }^{308}$ Thus, it seems inconsistent to bring Kissinger to bear for the Laos and Cambodia bombing campaigns while dismissing Nixon. On the other hand, war crimes tribunals have historically prosecuted both the highest superiors (i.e. Milosevic) and lower-level officials (i.e. Adolf Eichmann or Jean-Paul Akayesu).

Overall, we must ask what effect a potential trial of Kissinger will have on future U.S. conduct and accountability. Is the United States ready and willing to accept the idea that there is a higher arbiter of justice than even the Supreme Court, and that if a government official makes a questionable decision or engages in a dubious act he may face the justices of an international court like the ICC? Certainly this question becomes particularly relevant in the context of the war in Iraq and within the overall parameters of the U.S. war on terrorism. In the end, individual accountability and restraint from overly militaristic foreign policy may be a desirable outcome.

As for the ICC itself, our analysis leaves a clearer understanding of its role, purpose, and design. The ICC is not meant to serve as a common court of judgment for even medium-level perpetrators. Its governing statute and historical legacy both point to the same conclusion: that the court's objective is to try the highest-level perpetrators of the most heinous crimes. This, more than anything else, helps us comprehend how Kissinger could escape liability for three of the four allegations. The ICC is an imperfect mechanism that reflects a limited funding pool and a hesitant international community. Perhaps the best way to view the ICC is not as a finished product, but as a stepping-stone to a more complete court, to be established at some point in the future.

308. See Truman Presidential Muscum and Library, The Buck Stops Here, at http://www.trumanlibrary.org/buckstop.htm (last visited June 5, 2004). 
